\title{
A NATUREZA INTERFACIAL DA LEXICOGÊNESE: A FORMAÇÃO DE PALAVRAS E ALGUMAS DAS SUAS INTERCONEXÕES COM A GRAMATICALIZAÇÃO, A FILOLOGIA E A SINTAXE
}

\section{THE INTERFACE NATURE OF LEXICOGENESIS: WORD FORMATION AND SOME OF ITS INTERCONNECTIONS WITH GRAMMATICALIZATION, PHILOLOGY AND SYNTAX}

\author{
Mailson Lopes* \\ UFBA
}

Resumo: São delineadas, neste artigo, algumas reflexões sobre a natureza multiface da formação de palavras, fenômeno semântico-(morfo)lexical que se estrutura como uma rede de conexões entre praticamente todos os níveis/âmbitos da língua, o que sinaliza a sua pertinência como objeto investigativo (primordial ou tangencial) para diversos campos dos estudos sobre a realidade linguística, notadamente os de ordem lexicológica e morfológica. Com ênfase no fenômeno da prefixação - e adotando como bússolas teórico-epistemológicas gerais alguns princípios da teoria da complexidade (CAPRA, 1997; MORIN, 2003; ECO, 2013), do pensamento sistêmico (KASPER, 2000; VASCONCELLOS, 2002) e da abordagem multissistêmica da linguagem (CASTILHO, 2002, 2003, 2007, 2009, 2010, 2011; MÓDOLO; BRAGA, 2012) —, buscar-se-á deslindar formas de contato entre a lexicogênese de cariz morfológico e os fluxos de gramaticalização, a sintaxe (articulação de cláusulas), perpassando por interconexões estabelecidas com a filologia.

Palavras-chave: Lexicogênese. Interfaces. Formação de palavras. Prefixação.

\begin{abstract}
In this paper, some reflections on the multifaceted characteristic of word formation are outlined, a (morph)-lexical semantic phenomenon that is structured as a network of connections between practically all levels/spheres of language, which generates its relevance as an investigative object (primordial or tangential) for different fields of studies on linguistics, notably to those of lexicological and morphological order. With an emphasis on the phenomenon of prefixation - and adopting as general theoreticalepistemological compasses some principles of Complexity theory (CAPRA, 1997; MORIN, 2003; ECO, 2013), systemic thinking (KASPER, 2000; VASCONCELLOS, 2002) and the Multisystemic language
\end{abstract}

* Doutor em Língua e Cultura pela Universidade Federal da Bahia (UFBA), em regime de cotutela com a Universidade de Coimbra
(UC); Professor de Língua Espanhola da UFBA. ORCID: https://orcid.org/0000-0003-3926-0494. E-mail: mailson.lopes@ufba.br. 
approach (CASTILHO, 2002, 2003, 2007, 2009, 2010, 2011; MÓDOLO; BRAGA, 2012) —, it will be sought to unravel ways of contact between morphological lexicogenesis and grammaticalization flows, syntax (articulation of clauses), going through interconnections established with Philology.

Keywords: Lexicogenesis. Interfaces. Word formation. Prefixation.

\section{INTRODUÇÃO}

[...] para llegar a un conocimiento más completo sobre algo, se necesita combinar varias perspectivas, utilizar diferentes metodologías, colaborar con otras áreas, y sobre todo, mantener una filosofía inquisitiva, abierta. ${ }^{1}$ (IBARRETXEANTUÑNANO, 2010, p. 64).

Nos marcos da linguística contemporânea, germina e desenvolve-se uma nova óptica epistemológica (que, como toda síntese científica, se apoia em contribuições de propostas precedentes, do lastro subjacente herdado), da qual derivam diversos marcos teóricos, mas que apresentam como núcleo comum uma postura de maior recusa a formulações de tópicos que se apoiam em uma compreensão das categorias linguísticas como imutáveis e engessadas. Como postula Borba (2003, p. 171): "Não há dúvida de que a linguagem é categorizada, mas há evidências de que essa categorização é não-discreta, com delimitação imprecisa, com definições contínuas e contingentes”. Consolida-se, assim, uma compreensão mais holística do sistema linguístico, visto como heterogêneo, que, além de plural e cambiante, incorpora as características de fluidez e contiguidade entre níveis e categorias.

Partindo-se de um estágio anterior (mas ainda vigente para diversos cientistas da linguagem), em que dominava o pensamento cartesiano, linear ou mesmo arbóreo, chega-se, então, a um modelo labiríntico - nas palavras de Eco (2013) - ou rizomático, complexo, com as devidas modificações que esse câmbio apresenta: a substituição de um pensamento disjuntivo (que isola e separa) por um pensamento que distingue e une, que é tecido junto, no sentido etimológico do termo complexus (MORIN, 2003). Em suma, trata-se de um paradigma epistemológico de caráter multidimensional ${ }^{2}$, enciclopédico, que engloba grande variedade de abordagens e ramificações (nas mais variadas áreas do conhecimento) e que tem como alguns de seus veios teóricos o modelo do pensamento sistêmico ${ }^{3}$ (FLOOD; CARLSON, 1988; KASPER, 2000; VASCONCELLOS, 2002) e a teoria da complexidade ${ }^{4}$ (CAPRA, 1997; MORIN, 2003; ECO, 2013).

\footnotetext{
1 “[...] para chegar a um conhecimento mais completo sobre algo, é necessário combinar várias perspectivas, utilizar diferentes metodologias, colaborar com outras áreas e, sobretudo, manter uma filosofia inquisitiva, aberta.” (IBARRETXE-ANTUÑANO, 2010, p. 64, tradução nossa).

${ }^{2}$ No sentido de que o conhecimento das partes depende do conhecimento do todo, como o conhecimento do todo depende do conhecimento das partes, que necessariamente são integradas, interconexas, não modulares (a não ser sob um viés estritamente metodológico). Trata-se de uma concepção sistêmica, hologrâmica (MORIN, 2003), comum a várias frentes do conhecimento, sobretudo a partir das duas últimas quadras do século XX, e que se contrapõe à concepção analítica, cartesiana, reducionista ou modular (KASPER, 2000).

${ }^{3}$ No entendimento de Flood e Carlson (1988), é um modelo cognitivo que observa a realidade, as coisas e os seres como estruturas complexas, como entidades globais, sob uma perspectiva visceralmente holística.

${ }^{4}$ Nesta, a realidade é vista metaforicamente como uma rede de relações, baseadas em padrões processuais de interações (CAPRA, 1997), que associam, em fluxos centrífugos e centrípetos, as partes e o todo, o todo e as partes.
} 
Algumas aplicações desses marcos teóricos no âmbito dos estudos sobre a linguagem são a linguística cognitiva, com as suas mais diversas ramificações, e a abordagem multissistêmica da língua, sendo esta elaborada e desenvolvida por Castilho, cuja filiação à teoria dos sistemas complexos fica patente (ou mesmo é mencionada) em diversas de suas publicações (CASTILHO, 2007, 2008, 2011). Tendo o mérito de ser uma teoria brasileira sobre o idioma (MÓDOLO; BRAGA, 2012), a abordagem desenvolvida por Castilho enfoca a língua como um fenômeno dinâmico, complexo, formado por subsistemas que atuam simultânea e cooperativamente: o léxico, a semântica, a gramática e o discurso, acionados por um dispositivo sociocognitivo central (MÓDOLO, 2012). Dessa integração, surgiriam os diversos processos operacionais que configuram e reconfiguram a estrutura linguística: a lexicalização, a semanticização, a discursivização e a gramaticalização. Por conseguinte, toda e qualquer expressão linguística exibirá características lexicais, discursivas, semânticas e gramaticais (CASTILHO, 2008, 2011). Essa assertiva é o mote para as reflexões expostas neste texto, tendo em vista os escopos a ele associados.

Não se manifesta, contudo, para este breve artigo, uma filiação indiscutível e apriorística às correntes epistemológicas e linguísticas supramencionadas. Não se trata de uma associação basilar, mas acidental, no sentido de que são alguns princípios que as norteiam que podem ser tomados como referência e inspiração para justificar o propósito deste texto, em que perpassa o juízo de que a língua é um sistema fundamentalmente dinâmico, em cujos fenômenos atuam diversas instâncias e que, portanto, se mostra como um fenômeno que possibilita um olhar científico integrador, que aprecia o diálogo entre diferentes teorias e diferentes níveis de análise.

O que parece ser um fenômeno já consabido e firmado, a formação de palavras, desponta como algo muito mais complexo, com patente diversidade empírica, sendo, como aponta Rio-Torto (1998, p. 51), “[...] uma área de actividade linguística cuja especificidade e cujo lugar têm sido e continuam a ser objeto de concepções substancialmente diversas”. Trata-se, indubitavelmente, de uma área de plena intersecção entre os domínios linguísticos, sobretudo o da gramática e o do léxico (PENA, 1995). Suas vias são intrinsecamente multiformes, alcançando diversos domínios da língua e, concomitantemente, sendo por eles influenciadas, não se limitando, por conseguinte, a aspectos formais, mas se plasmando nos domínios morfológico e lexical, em coarticulação com a fonologia, a semântica, a sintaxe e a pragmática, uma vez que os processos derivativos e compositivos implicam categorizações e recategorizações fonológicas, morfológicas, lexicais, semânticas, sintáticas e pragmático-discursivas.

Adota-se, neste artigo, consequentemente, uma postura que concebe a formação de palavras como inscrita na morfologia, mas em contínua interação com os demais níveis da gramática (DEPUYDT, 2009; SILVA, 2006; PENA, 1999; RODRIGUES, A. F. S., 2016; RAE; $A_{A} E^{5}$, 2009). Constituem, nos termos de Rodrigues, C. V. (2000), relações abstratas (pensa-se ser preferível denominá-las de relações virtuais) associadas a processos cognitivos, que licenciam a organização de regras lexicogênicas ${ }^{6}$. Entende-se, aqui, com Basilio (2012, p. 1),

\footnotetext{
${ }^{5}$ RAE - Real Academia Española; AALE - Asociación de Academias de la Lengua Española.

${ }^{6}$ Ainda que pouco usual na tradição linguística brasileira, o termo lexicogênese (e derivados) é frequente no âmbito da linguística espanhola (lexicogénesis) e inglesa (lexicogenesis) e parece ser um termo muito adequado para designar os processos de criação e renovação do léxico, dentre os quais se enquadram os esquemas morfológicos de gênese vocabular (em outros termos, os processos morfológicos de formação de palavras). Não é supérfluo salientar que há procedimentos lexicogenéticos — vías lexicogenésicas, em castelhano (GARCÍA PLATERO, 1998) — que não recorrem a operações morfológicas. Nas palavras de Villalva (2008), são
} 
que: "Construções lexicais são complexos de propriedades sintáticas, semânticas, morfológicas, fonológicas e pragmáticas, que se associam ao conhecimento enciclopédico”. Desvela-se, portanto, como um setor policêntrico e polidimensional, domínio de confluência de diversos componentes da gramática, possuindo grande complexidade, tanto pela capacidade gerativa que apresenta quanto pelo rol de variáveis com que opera (CAMPOS, 2004a).

A prefixação ${ }^{7}$ pode ser concebida como o processo adjuntivo de partículas mórficas (em geral formas presas ou dependentes) à margem esquerda do vocábulo que lhes serve de suporte categorial e léxico (geralmente um verbo ou um nome), ordinariamente fornecendo a essa base a que se agregam um conteúdo semântico subsidiário (podendo ser de natureza lexical, funcional (gramatical), distintiva, categorial ou modificacional) ${ }^{8}$, que matiza ou precisa sua significação, não engatilhando essa adjunção, na maior parte das vezes, um processo de transcategorização ${ }^{9}$. Tal como afirma Rio-Torto (1998), a operação prefixal pode geralmente ser formalizada no esquema $[\mathrm{X}]_{\mathrm{y}} \rightarrow$ [prefixo $\left.[\mathrm{X}]_{\mathrm{y}}\right]_{\mathrm{y}}$, em que $\mathrm{X}$ representa a base, e Y a categoria sintática desta. Exemplificando: $[\text { contar }]_{\mathrm{V}} \rightarrow\left[\text { des- }[\text { contar }]_{\mathrm{V}}\right]_{\mathrm{V}^{*}}$ O prefixo pode associar-se a uma palavra independente (antinatural, descuidar, inadmissível, predisposição) ou a um tema ou raiz presa (amorfo, antígeno, inerte, micróbio, progênie).

É possível considerar, portanto, que a prefixação é um fenômeno multifacetado e complexo, que inclui em suas operações partículas afixais que podem ser de distinta natureza, dado o seu grau de prototipicidade relativa a um continuum mórfico em cujos extremos figurariam o que é mais prototipicamente compositivo e o que é mais prototipicamente derivativo, envolvendo, é claro, uma caracterização [+ lexical] ou [+ gramatical]. Podem ser tidos como mais prototípicos os elementos prefixais dotados de carga semântica expressiva (mas subsidiária) que são exclusivamente formas presas, dotados da propriedade de constituição de paradigmas morfolexicais (formações em série, o que se associa à recorrência e à produtividade e vitalidade) e que não se enquadram como operadores heterocategoriais. Seriam, por conseguinte, os mais achegados ao polo [+ derivacional]. A partir desse protótipo, central e mais representativo da classe dos prefixos, irradiar-se-iam classes de formantes prefixais mais ou menos periféricos, com uma

recursos não-morfológicos de formação de palavras, como o redobro, as palavras onomatopaicas, a amálgama, a eponímia, a extensão semântica, o truncamento, a acronímia, a siglagem, a abreviação, o cruzamento vocabular e a hipocorização. Segundo essa morfóloga, são “[...] fenômenos de criação de palavras que por vezes são apresentados também como domínio da morfologia, mas que, em rigor, não o são” (VILLALVA, 2008, p. 52).

${ }^{7}$ A escolha da prefixação, neste artigo, dá-se apenas como um recorte para o desenvolvimento de comentários sobre a lexicogênese morfológica e as suas conexões com outros níveis, outras subdisciplinas ou outros marcos da teoria e da análise sobre a língua e sobre o texto. Como se poderá perceber, vários pontos das discussões delineadas nas seções seguintes podem ser aplicados a outros fenômenos morfológicos, como a sufixação e a composição.

${ }^{8}$ Cabe ressalvar que há diversas operações morfológicas em que um suposto prefixo (ou prefixoide), em vez de apresentar apenas uma carga semântica subsidiária à formação, comporta-se — quanto ao conteúdo semântico — como o morfema responsável pela significação principal do vocábulo (como se fosse uma verdadeira base léxica). Essa é uma situação geralmente identificada em operações prefixais cuja base lexical é fóssil. É o caso, por exemplo, do que ocorre nos vocábulos “contrário”, “maldade”, "benigno" e "circundar".

${ }^{9}$ São esporádicos, mas existentes, os casos em que os prefixos operam processos heterocategoriais. Ocorre, por exemplo, em “anti-FHC” (classe-fonte: subst.; classe-alvo: adj.) ou em “pró-reforma” (classe-fonte: subst.; classe-alvo: adj.). Atendo-se às operações mais prototípicas e generalizadas da prefixação e sufixação, pode-se cogitar que esses dois tipos de operações com morfemas léxico-gramaticais — denominação adotada por Soledade (1999) — engatilham fenômenos dispostos como em um reflexo especular, pois o primeiro ordinariamente atribui uma carga semântica lexical à base, sem normalmente mudar-lhe sua classe gramatical original; já o segundo, normalmente provoca uma determinação/mudança categorial, geralmente oferecendo um novo matiz semântico ao morfema lexical básico a que se agrega. 
ou mais características diferentes da classe nuclear prototípica ${ }^{10}$ : (i) os prefixos expletivos ${ }^{11}$, (ii) os prefixos opacos ${ }^{12}$, (iii) os prefixos transcategorizadores (ou heterocategoriais), (iv) os prefixos com comportamento de bases lexicais ${ }^{13}$, (v) os prefixoides ${ }^{14} \mathrm{e}$ (vi) os pseudoprefixos ${ }^{15}$.

Calcando-se na constatação da irrefutável natureza interfacial da constituição do sistema intralinguístico de qualquer idioma, pretende-se desenrolar, nas próximas seções deste escrito, um conciso diálogo entre algumas instâncias que coatuam (ou se permitem entrever) no processo de formação de palavras (mormente a prefixação): a gramaticalização, a filologia e a sintaxe.

\section{FORMAÇÃO DE PALAVRAS E GRAMATICALIZAÇÃO}

Segundo Barreto (2012, p. 409), a gramaticalização consiste em um processo em que “[...] itens lexicais com referências extralinguísticas desenvolvem significados gramaticais ou itens já gramaticais se tornam ainda mais gramaticais. A gramaticalização parte do léxico em direção à gramática, abrangendo mudanças fonológicas, morfológicas e sintáticas”. Quanto a essa caracterização do fenômeno, similarmente a concebe Fernández Jaén (2009) e muitos outros teóricos: Hopper (1991), Hopper e Traugott (1993), Castilho (1997), Chagas (2002). Sintetizando-se os pontos expressos nesses estudos, pode-se afirmar que a gramaticalização é um tipo especial de mudança linguística, que abarca unidades e construções linguísticas inseridas

\footnotetext{
${ }^{10}$ Para uma caracterização pormenorizada de cada uma dessas classes de unidades prefixais, conforme estudos de Lopes (2013, 2014, 2018).

${ }^{11}$ Prefixos expletivos são os que não parecem oferecer acréscimos semânticos às bases a que se acoplam. São, assim, destituídos de qualquer carga semântica identificável ou recuperável (daí se diferenciarem dos opacos, cuja carga semântica, ainda que não transparente, é recuperável através de uma recorrência à etimologia). São expletivos, por exemplo, o $a$ - em “aparafusar” (sinônimo de "parafusar") e o $e$ - em "emoldurar" (sinônimo de "moldurar”).

${ }^{12}$ Tanto os prefixos expletivos quanto os prefixos opacos são assemânticos, mas se diferem justamente na natureza de tal assemanticidade: enquanto os expletivos se mostram sempre semanticamente vazios, em todo o percurso diacrônico do vocábulo em que figuram, os opacos permitem detectar algum matiz semântico por eles veiculado, algo recuperável através de uma incursão etimológica, que geralmente retrocede até o latim. O processo de opacidade nos formativos (e também nas bases) liga-se a fluxos históricos de paulatina erosão do conteúdo, tornando-os destituídos de transparência semântica. Isso explica o fato de os prefixos opacos geralmente figurarem em formas herdadas, cunhadas no latim, sendo de constituição morfológica bastante recuada. Exemplos de unidades prefixais semanticamente opacas seriam o ad- em "advertência”, o ob- em "obcecado" e o per- em "permanecer".

${ }^{13}$ Segundo Lopes (2018), os basoides prefixais, também denominados prefixos-base ou prefixos com comportamento de base lexical, são partículas que coincidem formalmente com algum elemento prefixal, mas que, diferentemente destes, portam a carga semântica principal do derivado, mostrando-se, portanto, quanto ao significado e à função, como uma verdadeira base léxica/ radical, e.g.: os segmentos contr(a)-, entr-, infer- e mal- em “contrário”, “entrada”, “inferno” e "maldade”. Sua transformação de afixo a base lexical é decorrente da fossilização e/ou da erosão fonológica da respectiva base original, decorrida ao longo do tempo. Daí o seu caráter prefixal só ser depreendido a partir do rastreamento diacrônico ou de um processo de comutação, sendo praticamente invisível a análises estritamente sincrônicas.

${ }^{14}$ Prefixoides são elementos atinentes ao espectro prefixal denotadores de matizes semânticos plenos e genéricos (correspondentes aos veiculados por formas livres ou a formas dependentes de explícita carga semântica de teor lexical), que gozam de relativa produtividade/ vitalidade e que possuem uma acentuada independência sintática. Inicialmente, eram formas adverbiais ou preposicionais que, graças a uma recorrente justaposição sintática à esquerda de alguns vocábulos, começaram a sofrer um processo de gramaticalização, passando a comportar-se semelhantemente a prefixos, ainda que conservando, na grande maioria dos casos, seus respectivos significados originais (CAMPOS, 2004). Seriam as formas bem-, contra-, mal-, não- e sem-, em "bem-amado”, “contra-argumento”, “malcriado”, "não-formal”, "sem-teto" etc.

${ }^{15}$ Pseudoprefixos são partículas de origem grega ou latina que, em formações recentes, passaram a assumir o conteúdo semântico total do vocábulo a que inicialmente se acoplavam — i.e., a sua "palavra-modelo” (GONÇALVES, 2016a) ou "palavra-gatilho" —, como bio-, que originalmente significava "vida” nas palavras-modelo "biologia” ou "biológico”, passando recentemente por uma transformação semântica, denotando, em vocábulos neológicos, o sentido de "biologia, biológico”, como em "bioenergia”, "biocombustível”, "biodiesel”, "biopirataria” etc.
} 
em complexas cadeias de variação e mudança, não raras vezes sob contínua transformação, graças a pressões intralinguísticas, mas também pragmático-discursivas.

Seria, portanto, a gramaticalização um processo de cristalização gramatical das estruturas linguísticas com mais expressiva produtividade na língua, sendo, destarte, uma rota por meio da qual um item mais lexical vai paulatinamente se tornando mais gramatical, passando de uma classe aberta a uma fechada (CASTILHO, 1997, 2004; POGGIO, 2002), a que acompanham, em geral, os seguintes fenômenos: o esvaimento (modificação ou perda de conteúdo semântico), a fixação em uma posição determinada (fixação sintagmática) e a erosão (perda de substância fônica). Esses processos seriam a tríade de sintomas paramétricos da gramaticalização (LAMIROY, 2004).

Como é possível perceber, a gramaticalização implica mudanças em três zonas centrais da estrutura linguística: na semântica/pragmática, na morfologia/sintaxe e na fonologia (DELANCEY, 2000). Até onde se sabe, foi Meillet (1948) o primeiro a empregar o termo gramaticalização (LEHMANN, 1985; HOPPER, 1991; POGGIO, 2002; DELANCEY, 2000) — , tendo, de certa forma, precursores que poderiam ser remontados ao século X (HEINE; ULRIKE; HÜNNEMEYER, 1991). Indica Poggio (2002) a existência de três grupos sucessivos que abordaram a gramaticalização: o primeiro, de Meillet (1912) até 1970, operando com o léxico e a gramática para a compreensão do fenômeno; o segundo, a partir de meados de 1970, operando com o discurso pragmático e a gramática; por fim, o terceiro, sobretudo a partir da década de 1980 (CUENCA; HILFERTY, 1999), operando com aportes cognitivistas. De acordo com Evans (2007), o fenômeno recebeu grande atenção por parte da Linguística Cognitiva sendo uma de suas searas investigativas mais frutíferas (GRAS, 2010) — , devido ao fato de costumar implicar entrelaçamentos de mudanças formais e semânticas (sendo, por conseguinte, um fenômeno atinente ao significado), bem como ser engatilhado pelo uso.

Um percurso de gramaticalização pode ser vislumbrado no processo de formação dos prefixos, pois, como defende Romanelli (1964, p. 15-16), a princípio, no próprio indo-europeu, existiam formas casuais (de valor locativo e instrumental) que, nessa mesma língua, acabaram fixando-se como advérbios de sentido concreto — de lugar e de tempo, segundo Bassetto (2010) —, vindo a transformar-se, já no latim, em preposições e, em seguida, em prefixos (verbais ou nominais). Oliveira (2007, p. 36), por sua vez, afirma que o indo-europeu primitivo “[...] dispunha de uma série de partículas que se colocavam com o verbo. Mais tarde, no latim, houve um processo de aglutinação de partículas adverbiais antepostas ao verbo, responsável pelo desenvolvimento do sistema prefixal latino [...]". ${ }^{16}$ No caso da formação dos prefixos, a cadeia de gramaticalização que a fundamentou provavelmente foi a seguinte: formas casuais $>$ advérbios > preposições > prefixos. Nota-se, assim, o percurso usualmente observável nesse processo: forma livre $>$ forma dependente $>$ forma presa.

No indo-europeu já havia um uso recorrente de elementos sufixais, pois admitia a adjunção à direita, ou seja, a sufixação, que se mostrava nessa língua como um processo fundamental e recorrente na constituição do léxico geral (BASSETTO, 2010; ROMANELLI, 1964). Não

\footnotetext{
${ }^{16} \mathrm{O}$ processo de prefixação inexistia no indo-europeu comum, não possuindo essa língua prefixos, tampouco preposições (BASSETTO, 2010; ROMANELLI, 1964). Não admitia qualquer forma de adjunção de partículas à periferia esquerda do elemento radical, a não ser o redobro verbal ou nominal (ROMANELLI, 1964). A prefixação parece apresentar-se, portanto, como um processo tardio, um fenômeno inovador, apenas atuante a partir do desenvolvimento das línguas descendentes do indo-europeu (BASSETTO, 2010; ROMANELLI, 1964).
} 
admitia, contudo, a adjunção afixal na margem esquerda. Na verdade, ao que parece, nem mesmo no latim clássico esse processo (a afixação à esquerda) já estava plenamente instaurado, pois, como alega Iacobini (2004):

[...] nelle lingue classiche, mentre i suffissi erano elementi che avevano concluso il loro processo di grammaticalizzazione, ed erano quindi usati esclusivamente come forme legate senza equivalente tra le forme libere della língua, i prefisse erano meno coesi con le parole a cui si univano, e vi erano evidenti rapporti fra le preposizioni correntemente impiegate nella construzione di sintagmi e alcuni fra i prefissi impiegati nella formazione di parole complesse. ${ }^{17}$ (IACOBINI, 2004, p. 102).

O formativo intro- ilustra perfeitamente o processo de gramaticalização que deu origem às partículas prefixais. De acordo com Romanelli (1964), sendo a princípio um advérbio pleno, assumiu também, tempos depois, a função de preposição, justapondo-se, em seguida, a alguns verbos, como autêntico prevérbio (prefixo, portanto) e, assim, permaneceu, sem qualquer variante ortográfica, como se observa nos seguintes exemplos: introeo, intromitto, introversus.

Na escala mórfica (LOPES, 2013), parece haver uma tendência de as formas [+ lexicais], conexas ao polo [+ composicional] do continuum composição-derivação, migrarem paulatinamente para o polo [+ derivacional], tornando-se muitas vezes [+ gramaticais], além de progressivamente menos independentes. Com Albuquerque (2010), Campos (2001, 2002, 2004a, 2004b, 2004c, 2007, 2009) e Alves (2000), pensa-se aqui que isso reflete, de forma clara, um percurso de gramaticalização ${ }^{18}$, isto é, um deslizamento paulatino de um item do léxico em direção à gramática, integrando-se em um paradigma mais fechado e passando a ocupar uma posição mais fixa no eixo sintagmático (LEHMANN, 1982, 1991). No caso dos prefixos, prefixoides e pseudoprefixos, há a transformação de um lexema em um morfema léxico-gramatical (STEIN, 1970). Com isso, pode-se considerar, então, que “[...] os prefixos são antigas formas livres que, por um processo de gramaticalização, tornaram-se formas presas em português” (CAVALIERE, 2000, p. 308). Exemplificando esse processo, declara Alves (2000) o seguinte:

Muitos dos elementos que estudamos, os formantes aos quais atribuímos um caráter prefixal, têm passado pelo processo da gramaticalização: formantes adverbiais como não e preposicionais como sobre passam a exercer função afixal e tornam-se prefixos; formantes que, no latim e no grego eram radicais, como o grego mega, passam também a atuar como afixos e a exercer igualmente uma função gramatical. (ALVES, 2000, p. 85).

\footnotetext{
17 “[...] nas línguas clássicas, enquanto os sufixos eram elementos que haviam concluído seu processo de gramaticalização e, portanto, eram usados exclusivamente como formas presas e sem equivalente entre as formas livres da língua, os prefixos eram menos coesos com as palavras a que se uniam, e daí haver relações evidentes entre as preposições atualmente usadas na construção de sintagmas e alguns dos prefixos empregados na formação de palavras complexas” (IACOBINI, 2004, p. 102, tradução nossa).

${ }^{18}$ Em virtude de seu caráter necessariamente sucinto, não se entrará neste escrito em uma discussão pormenorizada sobre a fronteira, a diferenciação ou a convergência entre os processos de gramaticalização e lexicalização, embora algo sobre esse último fenômeno seja exposto ao fim desta seção. Trata-se de uma verdadeira vexata quaestio para os estudiosos da área, de tal forma que muitos os consideram como fenômenos idênticos ou, quando os tentam diferenciar, sequer conseguem chegar a uma fronteira nítida entre um e outro processo. O limite entre a gramaticalização e a lexicalização é muito tênue, sendo processos contíguos e com muitas características em comum. Pode-se considerar que o que realmente pode distinguir um e outro fenômeno são o input e o output de cada um deles (BARRETO, 2012). O estudo de Santos (2012) parece corroborar essa afirmação, mas, ao mesmo tempo, traz outros meandros conceituais para o processo de lexicalização, o que denota, de certa forma, a polissemia do termo, suas ramificações definitórias e a mutabilidade de sua caracterização, de uma corrente teórica a outra. Para uma reflexão mais detalhada sobre essas questões, ver estudo doutoral de Lopes (2018).
} 
Existe uma gradação (via gramaticalização) na escala do continuum composição-derivação, que vai do que é mais compositivo ao que é mais derivativo, em que transitam, muitas vezes difusamente, as unidades e categorias morfolexicais (GONÇALVES, 2011b). Essa migração se realiza a partir da recorrência: quanto mais recorrente, mais um elemento afixal de margem esquerda se aproxima da derivação, ilação captável no estudo de Azeredo (2000, p. 69), quando afirma que: "Na história da língua portuguesa, algumas palavras lexicais tornam-se gramaticais por causa de sua freqüência de uso em certa posição, o que acabou enfraquecendo o significado lexical delas”. Assim, a gradação seria: radical livre $\rightarrow$ radical preso $\rightarrow$ pseudoprefixo $\rightarrow$ prefixoide $\rightarrow$ prefixo, podendo haver saltos de etapas realizados por alguns elementos. A diferença mais expressiva, portanto, entre um prefixo, um prefixoide e um pseudoprefixo seria de caráter histórico-diacrônico, ou seja, o grau de gramaticalização: os primeiros (no caso, os prefixos) são resultantes desse processo; os últimos são formantes que, em menor ou maior grau, ainda se encontram sob esse processo, deslizando por sobre o percurso gradativo do continuum mórfico, estando “a meio caminho” entre a composição e a derivação (CAETANO, 2010).

Rio-Torto (2016) procede a uma pertinente análise da escala de gramaticalização das preposições apontada por Castilho (2004) — estruturada em três divisórias, a de preposições mais gramaticalizadas, medianamente gramaticalizadas e menos gramaticalizadas —, chegando à interessante constatação de que as mais gramaticalizadas coincidem com prefixos de grande rentabilidade genolexical ( $d e-, e m-, a-, c o m-)$, as medianamente gramaticalizadas, com alguns prefixos locativos e avaliativos (sob-, sobre-, entre-, contra-, pos-), e as menos gramaticalizadas, com o prefixo ante-. Se, além da escala de gramaticalização prefixal, fosse apreciada a escala de gramaticalização adverbial — algo que poderia ser depreensível, por exemplo, dos estudos de Costa, mormente os de 2003, 2009 e 2012 —, provavelmente se chegaria a conclusões igualmente interessantes, que talvez conduzissem a uma constatação de que o grau de gramaticalização dos principais formantes prefixais (ou seja, a diferenciação entre prefixo e prefixoide) vai coincidentemente atrelado via correspondências mais ou menos sistemáticas ao grau de gramaticalização das formas livres ou dependentes das quais se originaram.

Um esboço de um continuum mórfico compositivo-derivativo em português (confira mais adiante) não apenas demonstra a não-modularidade entre as subcategorias mórficas (tal como ocorre nos demais níveis da língua), mas também uma linha gradiente que explicita um percurso que vai do mais compositivo [+ lexical] ao mais derivativo [- lexical], chegando até os itens mórficos destituídos de significação (morfemas de sentido opaco e morfemas expletivos). Assim, de certa forma, o continuum traz consigo a indicação de um percurso de gramaticalização na formação e evolução das partículas mórficas, ou seja, uma rota processual diacrônica por meio da qual um item [+ lexical] vai paulatinamente se tornando mais gramatical — i.e., [- lexical] —, passando de uma classe mais aberta a uma mais fechada, ocorrendo com isso, geralmente, um enfraquecimento ou apagamento de seu conteúdo semântico, o que se dá nos morfes opacos e nos expletivos, respectivamente. 
Figura 1: Esboço de um continuum mórfico compositivo-derivativo em português

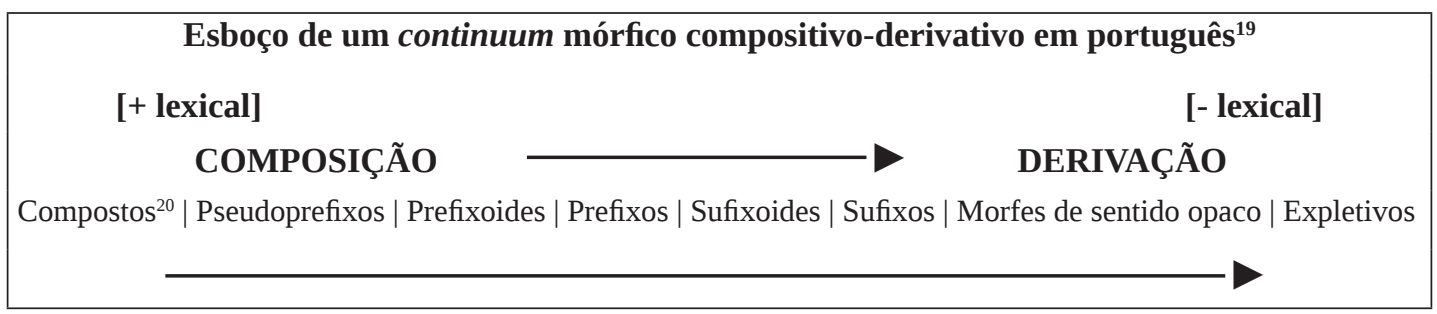

Fonte: Lopes (2013, p. 92).

Para exemplificar esse percurso, pode-se utilizar o item mórfico -latra, com base no estudo realizado por Nascimento (2012): um elemento neoclássico, considerado pelas gramáticas tradicionais como um radical que participa do processo de composição, mas que vem sofrendo, em uma perspectiva diacrônica, um processo de gramaticalização, afastando-se de uma configuração como forma livre (como originalmente o era, no grego clássico) e assumindo, paulatinamente, um caráter mais abstrato e funcional, juntamente a uma opacidade semântica, com sentido recuperável apenas ao anexar-se a uma base. Assim, tal partícula não mais se identifica como um elemento compositivo, por estar se aproximando, dentro de um continuum, do polo derivacional.

Como se ilustrou anteriormente, o surgimento de novas partículas prefixais parece ocorrer por meio de cadeias de gramaticalização, ampliando o rol de prefixos vernáculos (contrariando a ideia de os prefixos constituírem um elenco fixo e estável). Pensa-se, com base em postulados funcionalistas, que é a rotinização, ou seja, a frequência no uso, que faz com que certa estrutura se gramaticalize e ingresse no rol do léxico geral da língua.

Como exemplos de gramaticalização de partículas afixais da margem esquerda do vocábulo na língua portuguesa, pode-se tomar o antepositivo al- árabe e o elemento não-. Lopes (2018, 2013) e Lopes e Soledade (2013) incluem a supramencionada partícula árabe no número de formas prefixais da língua portuguesa e o fazem com base em sua configuração recorrente em uma posição esperada no interior da estrutura mórfica do vocábulo (afixa-se sempre à sua extremidade esquerda), o que, ao mesmo tempo, é fruto e causa da gramaticalização que ocorreu no artigo árabe al, que migra do rol das formas dependentes para o grupo das formas presas. Trata-se, pois, de um percurso recorrente nos fluxos de gramaticalização (COSTA, 2004; CASTILHO, 1997, 2003; POGGIO, 2002), já que, inseridas em um esquema de continuum, “[...] categorias lexicais dão surgimento a categorias gramaticais, e estas a categorias ainda mais gramaticais, entendendo-se por isto os afixos" (CASTILHO, 2003, p. 248). De forma semelhante ao ocorrido com os prefixoides, com os pseudoprefixos e mesmo com os prefixos latinos, a inserção do antepositivo árabe nas categorias afixais decorreu de um processo de gramaticalização, reforçando a proposta de um continuum composição-derivação para o português (GONÇALVES, 2011a), bem como para as demais línguas românicas. Para tanto, pesa, ainda, o fato de esse processo decorrer de uma situação de contato linguístico, em que a gramaticalização sofreu a pressão de

\footnotetext{
${ }^{19}$ Esse esboço visa a englobar exclusivamente as formas presas da língua portuguesa envolvidas em processos genolexicais (derivativos ou compositivos). Pode ser caracterizado, portanto, como um continuum tipológico morfolexical, já que a formação de palavras se estabelece em uma interface léxico/morfologia.
} 
uma reanálise morfolexical posta em marcha pelos falantes da língua-alvo (romances/ línguas românicas) sobre a língua-fonte (o árabe).

Embora se considere o mencionado elemento árabe um elemento mórfico da margem esquerda vocabular, deve-se ressalvar que se trata de uma questão que demanda uma reflexão mais burilada, que igualmente leve em consideração, de forma mais aprofundada, a ilação oposta sobre o elemento árabe al- no interior do léxico ibero-românico, ou seja, a sua consideração como parte integrante da base léxica, como um artigo aglutinado, sem qualquer valor morfolexical.

Ao fundamentar-se nas reflexões de Jacob (2010) e Campos (2002, 2004a), a inserção do elemento não- no rol de partículas prefixais do português também poderia ser considerada como efeito de um processo de gramaticalização, por intermédio do qual o advérbio negativo se converte em um prefixo, migrando de um polo [+ lexical] para um polo [+ gramatical], operação essa que se processa há bastante tempo na história da língua portuguesa; na verdade, desde o princípio de sua manifestação como tradição escrita, como Lopes $(2013,2018)$ demonstrou, com base em rastreamentos em corpora documentais mediévicos. Sendo inicialmente uma forma livre adverbial, recategorizou-se, passando a funcionar como uma forma presa (CAMPOS, 2002, 2004a). Trata-se de uma partícula que possui um significado bastante generalizante, denotando uma ideia geral de "negação" às bases nominais a que se coaduna, funcionando como um recurso econômico do ponto de vista do falante (JACOB, 2010), além de ser um recurso alternativo para os utentes, que em vez de utilizar prefixos negativos tradicionais (como in-, $a$-, des- etc.), optam muitas vezes por fazer uso do prefixoide não- ${ }^{20}$.

Parece pertinente e útil a adoção de uma subclassificação dos elementos mórficos envolvidos no processo de formação de palavras via prefixação, com uma divisão dos elementos afixais da periferia esquerda do vocábulo sob a forma de um esquema tetrafatorial, com seus componentes identificáveis pelos termos "prefixo" (ou "prefixo propriamente dito" ou "prefixo stricto sensu”), "prefixoide” (ou "semiprefixo"), "basoide prefixal” (ou "prefixo com comportamento de base léxica”) e “pseudoprefixo”. Como já apontado, seriam subclasses prefixais, não modulares, diferentes (mas contíguas), com fronteiras difusas e imersas em uma escala gradual e que se diferenciariam, sobretudo, pelos seus diferentes graus de gramaticalização, tal como preconizam Alves (2000) e Lopes (2018).

Como encerramento desta seção, destaque-se a existência de um fenômeno de certo modo inverso ao da gramaticalização, que também se mostra atuante em partículas prefixais: a lexicalização. De acordo com Correia e Almeida (2012), em linhas gerais, esse processo se manifesta quando unidades pertencentes à gramática (sintaxe, morfologia, discurso) passam a funcionar como unidades lexicais de pleno direito. No domínio da afixação, consistiria na transformação de um morfema em uma unidade lexical, passando a usufruir de maior autonomia sintática,

\footnotetext{
${ }^{20}$ Observe-se, no entanto, que nem sempre a anteposição do elemento não- a um vocábulo corresponderá exatamente ao sentido de uma forma derivada possuidora de outro prefixo negativo, o que sinaliza que a alternância não é absoluta. Assim, por exemplo, não se nota uma correspondência semântica de equivalência entre, de um lado, os sentidos dos derivados verbais "despovoar”, “ilegalizar”, “inutilizar” e, do outro, os sentidos das construções “não povoar”, “não legalizar”, “não utilizar”, respectivamente. Isso porque, nesse segundo grupo de exemplos, o não funciona como expediente sintático de negação, não como elemento mórfico propriamente dito (afixoide). Na verdade, a explicação para isso parece atrelar-se à própria funcionalidade e ao valor semântico do prefixoide não-, antepositivo que serve à geração de formas denominais/deadjetivais isocategoriais — i.e., que atua em ambientes pré-substantivais e pré-adjetivais (DUARTE, 1999) — , com o aporte semântico de pura negação (mas não o de reversão ou o de contraposição/oposição em sentido estrito), como nos seguintes exemplos: “não tolerante” (em lugar de "intolerante”), “não frequente” (em lugar de “infrequente”), “não alinhado” (em lugar de “desalinhado”), “não alfabetizado” (em lugar de “analfabeto”).
} 
semântica, formal e funcional, migrando da classe das formas presas à classe das formas livres, desempenhando na cadeia sintagmática uma função geralmente substantiva. Esse trânsito representaria, por assim dizer, um verdadeiro processo de desgramaticalização (MENDES, 2013), como o que atinge, por exemplo, as formas bi, ex, super e vice nas construções "Ela contou para os pais que era bi", "O ex de minha irmã é super gente boa" e "O time não deve se contentar em ser vice”. A partir da leitura de Gonçalves (2016b), é possível concluir que a lexicalização afixal ocorre a partir de um processo de leitura metonímica por subparte, de modo que muito se aproxima de outro processo morfolexical gerador de neologia, o truncamento ${ }^{21}$.

\section{FORMAÇÃO DE PALAVRAS E FILOLOGIA}

A princípio, poucos elementos se encontrariam que pudessem manifestar uma associação teórica ou analítica automática entre a lexicogênese de natureza morfológica (i.e., os procedimentos morfológicos de formação de palavras) e a filologia. No entanto, por se adotar aqui uma perspectiva epistemológica que valoriza o caráter histórico da língua e o valor heurístico da empiria, pode-se dizer que há, sim, ligações perceptíveis entre esses campos do saber linguístico.

Afirmam Grossmann e Rainer (2004, p. 8), em seu compêndio de morfologia lexical para o italiano, que as bases empíricas são "[...] le caratteristiche indispensabili per un'analisi morfologica.", pois “[...] l'intuizione non è sempre così netta [...]"22 (GROSSMANN; RAINER, 2004, p. 10). Assertivas categóricas, mas que não causam qualquer espanto para aqueles formados no seio do Programa para a História da Língua Portuguesa (PROHPOR), visto que é a valorização do dado empírico uma das marcas desse grupo, uma herança viva do pensamento científico da sua fundadora, a linguista histórica Rosa Virgínia Mattos e Silva (in memoriam).

Ora, se para os estudos acurados concernentes à morfologia é uma conditio sine qua non a recorrência a dados empíricos, vê-se, em decorrência disso, que, se se aplicam a estágios mais recuados da língua, são dependentes dos testemunhos escritos remanescentes e, por conseguinte, do labor filológico, que visa a conceder aos linguistas o material empírico mais adequado possível para as suas incursões científicas. Que o estudo diacrônico se volte à filologia como parceira indispensável na empreitada de desvendar os rastros e rumos temporais das línguas é fato comprovado pelo seu próprio caráter empirista, do qual deriva a perspectiva metodológico-epistemológica de cunho indutivo que se entrevê nas pesquisas histórico-diacrônicas, necessariamente subordinadas ao acesso a fatos de língua, em outras palavras, ao dado empírico. Há, portanto, um trânsito constante e bidirecional, pois a filologia utiliza-se dos aportes da linguística para estudar os textos, e a linguística faz uso dos textos filologicamente editados para estudar a língua.

De toda a problemática que envolve o trabalho com o texto escrito produzido em fases pretéritas, a que se dedicam filólogos e linguistas, pode-se dizer que também se constitui como objeto epistemológico para a história da cultura escrita. Corrobora essa perspectiva a percepção de Petrucci (2003, p. 7-8), quando entende que o historiador da cultura escrita deve ocupar-se "[...] de la historia de la producción, de las características formales y de los usos sociales de la escritura y de los testimonios escritos en una

\footnotetext{
${ }^{21}$ Que nada mais é que a compactação do significado de uma palavra em um fragmento dela, como se dá em refri (de refrigerante), em otorrino (de "otorrinolaringologista”) e em motô (de "motorista”).

22 “[...] as características essenciais para uma análise morfológica”, pois “[...] a intuição nem sempre é algo claro [...].” (GROSSMANN; RAINER, 2004, p. 8, 10, tradução nossa).
} 
sociedad determinada."23 Pautando-se nisso, esta seção tentará explicitar o diálogo depreensível entre a filologia e o estudo da formação de palavras sob um viés histórico-diacrônico.

É evidente, tal como destaca Maia (2012), que o material linguístico empírico extraído dos registros escritos da produção medieval primitiva que chegaram até a contemporaneidade não se compara, sob um ponto de vista epistemológico e sociolinguístico, aos que o investigador hodierno consegue recolher por meio dos falantes, visto que esses dados apresentam características mais verossímeis e comprováveis que aqueles, sobretudo quando se tem em vista atestar a agramaticalidade de certas construções linguísticas. O texto é o testemunho mais concreto e complexo da língua do passado (FERREIRA, 2003; TELLES, 2000), sendo as ocorrências dos fatos linguísticos nele presentes os únicos objetos cientificamente observáveis, já que somente as averbações têm valor testemunhal (MARTIN, 2003). Há, portanto, uma realidade inexorável que se impõe ao linguista medievalista de formação epistemológica empiricista: o fato de somente conseguir se achegar à língua de outrora por intermédio de edições dos textos escritos remanescentes (essencialmente fragmentários, mas assaz importantes para a reconstrução da língua).

Nas palavras de Maia (2012, p. 537), “[...] as pesquisas linguísticas de base empírica, quer em matéria de ‘oralidade’ como de ‘escripturalidade’ têm que apoiar-se necessariamente em corpora”. Para períodos recuados da história, tal como apontam alguns expoentes da história da leitura e da cultura escrita, as fontes empíricas são sempre parciais e fragmentárias (CHARTIER, 2004), sendo mais restrita a sua variedade (SHARPE, 1992), o que leva a que sua seleção esteja imperiosamente submetida às vicissitudes documentais da sociedade de antanho e aos diferentes panoramas (acesso e disponibilidade) dos fundos, acervos e arquivos (MARQUILHAS, 2000).

Quando se propõe a investigar materiais de fases recuadas de uma língua, todo pesquisador precisa necessariamente se debruçar sobre os textos escritos remanescentes, dado o intransponível obstáculo da inexistência de registros da língua falada. Daí se poder afirmar, com base em Lopes (2013), que pelo menos sob cinco prismas os estudos em linguística histórica são parciais e provisórios, constituindo-se apenas em uma difusa aproximação à língua de outrora:

(i) as descrições, análises e teorizações linguísticas são fragmentadas e parciais, visto que se fundamentam, conforme assinala Telles (2011), apenas em material proveniente da modalidade escrita da língua, não se podendo incidir diretamente (por motivos óbvios) sobre a sua modalidade oral;

(ii) o material linguístico remanescente sempre será uma parcela mínima da produção original, que perdurou às vicissitudes históricas e à cáustica ação do tempo, não constituindo, de forma alguma, sua totalidade, sendo apenas um espólio fragmentado, resultante de acidentes históricos para além do controle do investigador (LABOV, 1982) ${ }^{24}$;

\footnotetext{
23 “[...] da história da produção, das características formais e dos usos sociais da escrita e dos testemunhos escritos em uma determinada sociedade.” (PETRUCCI, 2003, p. 7-8, tradução nossa).

${ }^{24}$ Um estudo sobre estágios recuados da língua, por mais abrangente que se creia ser, sempre será uma aproximação interpretativa parcial e fragmentada, visto que parciais e fragmentados são os espólios empíricos sobre os quais se debruça e, destarte, a documentação escrita sobre a língua enfocada só pode ser avaliada na sua totalidade de forma hipotética (MATTOS E SILVA, 1991, 2006). Cabe ao linguista que se ampara em edições de textos para proceder a uma reconstituição da língua medieval resignar-se ao quadro empírico fragmentado que tem ao seu dispor, já que sempre se encontrarão lacunas na reconstituição da língua de fases historicamente recuadas, não havendo como reconstituir todas as fases percorridas nem como descrever totalmente as contribuições geracionais que fizeram emergir as diversas camadas de sua estrutura, mormente de seu léxico, como afirma Abadde (2011).
} 
(iii) como o linguista geralmente se apoia em edições filológicas para apropinquar-se aos dados que objetiva descrever e analisar, vê-se indissociavelmente atado ao que é detectável por meio de tais edições, que nunca são neutras ou imparciais, já que sempre se escoram em critérios e posturas mais ou menos conservadores, o que não permite afirmar que exponham o texto original (ainda que tentem reproduzi-lo de forma fiel e completa), mas apenas uma imagem reflexa desse texto ${ }^{25}$, pois, "[...] por mais conservadora que possa ser uma edição, tem-se, ao fim e ao cabo, como resultado, um novo texto, já que existe sempre uma interferência subjetiva por parte de seu editor” (CUNHA E SOUZA, 2007, p. 255);

(iv) a impossibilidade, ao menos com os instrumentais metodológicos disponíveis até o momento, para um estudo sobre o léxico ou sobre a morfologia derivacional, de se realizar uma recolha de dados exaustiva em todos os textos remanescentes, o que, necessariamente, impele o estudioso a realizar um recorte representativo do conjunto textual a seu dispor. Essa imperativa situação no sentido de se fazer recortes sempre implicará em descrições, análises e teorizações parciais e provisórias;

(v) sempre há nas investigações analíticas sobre um período histórico recuado, de forma mais ou menos expressiva, interferências do olhar do estudioso como conhecedor e falante da língua contemporânea. Em outras palavras, não há como escapar de certo anacronismo no estudo de estágios pretéritos da língua, pois sempre se acaba enfocando a língua de ontem com os olhos de hoje, ainda quando se busca valer de um lastro empírico corroborante. Como impecavelmente expõe Wallerstein (2011, p. 43, grifo do autor): “The past can only be told as it truly is, not was" ${ }^{\text {26 }}$. De fato, o passado só pode ser concebido como é verdadeiramente, e não como foi. Por não se dispor do testemunho direto advindo da produção oral do falante nativo dessas épocas mais recuadas, os pontos de vista como falantes e conhecedores da língua contemporânea acabam por contaminar as perspectivas de análise, interferindo de alguma forma nas ilações desenvolvidas.

Há, assim, pelo menos cinco condicionantes histórico-filológicos sinalizadores de que todo e qualquer estudo histórico sobre estágios pretéritos da língua (mormente os mais temporalmente recuados) é parcial e aproximativo.

Um aspecto em que se vislumbra a dependência do estudo morfolexical ao labor filológico fica explícito ao se avaliar o efeito pujante que a onipresente variação gráfica estabelecida na produção textual do português arcaico (ou de outros estágios pretéritos do idioma) mobiliza na morfologia flexional ou derivacional desse período: a partir desse contexto intralinguístico é que se explica e se justifica a ampla gama de alomorfes e alógrafos depreendida da morfologia lexical dessa sincronia da língua portuguesa (LOPES, 2013; SOLEDADE, 2004). Para Mateus (2012, p. 15), essas variações gráficas incidentes sobre a morfologia do português medieval não são arbitrárias ou pontuais, mas se moldam, indubitavelmente, como “[...] fragmentos do esforço do escriba para transmitir aspectos da língua falada que não se compaginam com a escrita em latinorromance”.

A situação anteriormente aludida fica comprovada quando se observa, por exemplo, que o prefixoide (ou semiprefixo) bem- podia ser representado na primeira fase do português arcaico

\footnotetext{
${ }^{25}$ Concorda-se aqui, portanto, com Machado Filho (2008, p. 30), quando assevera que, “[...] por mais que conclame a crítica textual de ser capaz de recuperar a história genética de um texto, qualquer estudioso de bom senso há de compreender que o passado (re) construído pela inteligência humana é meramente 'uma aproximação' da realidade que se perdeu [...]”.

26 “O passado só pode ser contado como realmente é, não como foi.” (WALLERSTEIN, 2011, p. 43, grifo do autor, tradução nossa).
} 
ao menos por quatro formas gráficas distintas: be- bẽ- bem- ben-, situação compartilhada pelo prefixo ante-, que também contava com quatro variantes: ante- $\sim$ ant- $\sim$ ente- $\sim$ hẽnte(LOPES, 2013). Se compara-se, então, a produção textual circunscrita ao português arcaico com a sua atualização moderna, pautada em uma normativização ortográfico-gramatical generalizada e plenamente adotada, chega-se à constatação de que a escrita nos estágios iniciais da língua portuguesa era bem mais livre e flexível do que no período hodierno, de maneira similar ao que também ocorreu com o espanhol (SÁNCHEZ-PRIETO BORJA, 1992) e, muito provavelmente, com as demais línguas novilatinas, dada a ausência de explicitação dos padrões de uso prestigiado prescritos pela normativização gramatical (MATTOS E SILVA, 2006, 2010) e também a inexistência de uma ortografia balizadora, que, para o português, só viria efetivamente a firmar-se em inícios do século XX (MACHADO FILHO, 2001, 2009b, 2012).

Do exemplo anterior, constata-se que uma orientação mais achegada à conservação ou à modernização empregada para dada edição pode trazer sérias implicações ao estudo da alomorfia e da alografia nas unidades mórficas, já que uma lição mais inovadora tenderia a neutralizar as oposições e adotar um registro mais próximo da feição moderna da língua, o que poderia levar, por exemplo, que o prefixo bem- aparecesse apenas sob essa forma, omitindo-se/trasmudando-se as três outras registradas no documento original, reproduzidas no parágrafo precedente.

Fenômenos e elementos morfológicos específicos podem ou não ser levados em conta em uma determinada análise sobre fases primevas da escrita de uma língua, a depender dos pressupostos e atitudes epistemológicos de natureza historicista ou filológica adotados a princípio. Assim, a escolha de uma edição diplomática ou interpretativa de um mesmo testemunho textual pode levar o morfólogo a diferentes resultados e a diferentes conclusões, como se observa, por exemplo, a seguir, contrastando-se duas edições de um mesmo manuscrito trecentista português, o Flos Sanctorum, sendo a primeira paleográfica (MACHADO FILHO, 2003) e a segunda interpretativa (MACHADO FILHO, 2009a):

E uymos nas terras. dos Neffeos. ede Babilonia conpanhas de monges que adur poderiã séer cõtadas, enque uymos. que auia muytas uertudes e muyto bẽ. (Fólio 13v, col. 1, l. 28-31). (MACHADO FILHO, 2003, p. 55).

E vymos nas terras dos Neffeos e de Babilonia companhas de monges que adur poderiam seer contadas, em que vymos que havia muytas vertudes e muyto bem. (Fólio 13v, col. 1, l. 28-31). (MACHADO FILHO, 2009a, p. 51).

Assim, nesse caso, com o uso da edição diplomática do Flos Sanctorum, ganha-se com a variabilidade grafemática (manifestadora propícia da alografia e/ou da alomorfia), mas surge o problema das ligaduras e separações grafemáticas, pedras de tropeço no caminho do estudioso de morfologia histórica, sobretudo quando decide empregar ferramentas computacionais de depreensão de partículas mórficas. É o que se pode constatar nos excertos seguintes, extraídos do Flos Sanctorum. Pela própria natureza conservadora da edição (paleográfica) de Machado Filho (2003), no primeiro excerto a seguir, o elemento preposicional $a$ é apresentado como no manuscrito original, acoplado a duas formas de infinitivo com as quais constitui a perífrase verbal, mas que, em uma detecção informática ou em um rastreamento menos atento, poderia ser tomado incorretamente como unidade prefixal - a partícula $a(d)$-, em suas respectivas manifestações como as- ou $a$ - — . Já no segundo trecho (MACHADO FILHO, 2003), dá-se 
justamente o inverso: formas prefixais como o des- e o ante-, que hoje são registradas invariavelmente ligadas a suas bases léxicas, aparecem separadas delas na edição mencionada, reproduzindo o que ocorria no documento original, sendo também algo que traria problemas a uma análise computacional (rastreamento via localizadores ou processamento via geração de listagem de palavras, como, por exemplo, no WordSmith Tools), confirmando-se, assim, a imprescindibilidade da leitura manual (verbo ad verbum) nos estudos sobre formação de palavras nos primeiros séculos da escrita vernacular.

Ca saãẽ todos en tẽpo do pã colher assegar ou aseruir por el. en algũa guysa. assy que oque chus pouco gáanha tres. ou quatro Caffizes son. Desto filhã eles amayor parte edãna aseus Abbades pera os pobres. (Fólio 13v, col. 1, l. 16-21). (MACHADO FILHO, 2003, p. 55).

Edesquea osancto homẽ untou dũũ olyo bẽẽto des fezesse aquela ante parãça $e$ uirona todos mãceba como ante era. (Fólio 15v, col. 2, l. 17-20). (MACHADO FILHO, 2003, p. 59).

Princípio de suma importância é que toda decisão metodológica traz consigo implicações operacionais, epistemológicas e até mesmo ideológicas. Destarte, pode-se sustentar que o uso de edições mais conservadoras ou mais modernizadas poderá oferecer dados diferentes e pontos de vista diferentes para a análise, o que influenciará nos resultados da investigação. Isso se reflete tanto na consideração da alomorfia e alografia afixais quanto na própria depreensão e posterior análise dos afixos.

A filologia e a linguística histórica relacionam-se também desde níveis mais gerais, mais fundamentais, atinentes à própria questão do fazer científico e do conhecimento sobre a língua de antanho. Uma relação visceral, inegável e que tem fortes implicações epistemológicas, perpassando muitos dos procedimentos e dos resultados ligados ao estudo linguístico de natureza histórico-diacrônica. Se assim o é em geral, não o deixa de ser para as pesquisas voltadas especificamente ao nível morfológico da língua, o que leva a se pensar, com Swiggers (1998), no seguinte:

Que essa relação de englobamento - filologia e lingüística como caixas chinesas venha à luz nos grandes empreendimentos de lexicografia histórica, não deve nos espantar: é o trabalho filológico que nos ajuda a reconstruir a perspectiva temporal na história das línguas. A descoberta da cronologia interna é o resultado de um trabalho combinado de filologia e de lingüística: é este trabalho que é o fundamento da verdadeira lingüística histórica [...]. (SWIGGERS, 1998, p. 15).

Vê-se, assim, que há intersecções e implicações interessantes entre a filologia, a linguística em geral e a morfologia lexical histórica em particular, das quais esta subseção aspirou a ser uma despretensiosa amostra. 


\section{FORMAÇÃO DE PALAVRAS E SINTAXE (COM ÊNFASE NA ARTICULAÇÃO DE CLÁUSULAS)}

Indiscutivelmente, há várias interconexões entre a morfologia e a sintaxe, dentre as quais a que parece ser mais enfatizada é a que se estabelece entre a flexão morfológica e a concordância sintática. A marcação redundante do gênero via sintaxe, os morfemas de posição e a própria natureza das denominadas formas dependentes ${ }^{27}$ são outros exemplos dessa interação profícua entre esses dois domínios da língua. Por constatarem essas interconexões entre a morfologia e a sintaxe, há aqueles que defendem a adoção do termo "morfossintaxe”28, pois preconizam que é praticamente impossível dissociar esses dois níveis da língua. Daí que Minussi e Nóbrega (2014, p. 162) cheguem a afirmar que “[...] a estrutura morfológica é estrutura sintática”. E, também, que Divino e Pires (2018, p. 84) apontem a possibilidade de que “[...] os mesmos mecanismos sintáticos ou morfossintáticos que ocorrem entre as palavras no âmbito da oração ocorram internamente nas palavras. [...] que os mesmos mecanismos cognitivos também poderiam atuar nas estruturas das palavras e frases”. De certo modo, essa perspectiva também se verifica em estudos que tomam como norte a linguística cognitiva, adotando uma concepção não-modular do sistema linguístico, calcada na constatação da irrefutável natureza interfacial da constituição do sistema intralinguístico. Sob esse prisma, tal como apregoa Langacker (1987), os níveis da língua formariam um continuum de fronteiras não demarcadas.

Algo que, mesmo sendo indubitavelmente verdadeiro, pouco se é pensado nos estudos morfológicos é a presença de fenômenos e operações sintagmáticos na estruturação interna do vocábulo, de tal forma que se poderia defender o fato (respeitadas as devidas proporções) de a morfologia ser uma espécie de sintaxe interna ao vocábulo formal — i.e., uma concatenação sintagmática vocabular interna, devidamente hierarquizada, como aponta Pena (1991) —, mas com a aplicação concomitante de operações relativas ao eixo vertical da linguagem, as relações paradigmáticas, consideradas por Sandmann (1997) como o objeto epistemológico precípuo da morfologia ${ }^{29}$.

Quanto à relação entre sintaxe e formação de palavras, nomeadamente a derivação, é evidente que o processamento desta se subordina a pautas sintáticas quando seus produtos ocorrem imersos em um contexto frasal, como o indica Rodrigues, A. F. S. (2016). Daí que derivados em -oso ("gracioso", “delicioso", "bondoso” etc.), por serem nomes, não possam ocorrer nos mesmos contextos sintáticos de derivados em -mente ("graciosamente”, “deliciosamente”,

\footnotetext{
${ }^{27}$ A marcação redundante do gênero no eixo sintagmático pode ser ilustrada no SN em destaque na frase “A síndica é superresponsável”, em que o gênero feminino, além de ser morfologicamente marcado pelo morfema flexional de gênero - $a$, reflete-se também pelo determinante. Já no que diz respeito aos morfemas de posição, Zanotto (1986) define-os como resultantes da troca de posição dos semantemas, que pode ocasionar a mudança de classe gramatical, o que pode ser visto na oposição entre "amigo professor : professor amigo”. Tal oposição não é um fenômeno de cunho morfológico, mas, sim, exclusivamente sintático. Por fim, as denominadas "formas dependentes" (ou “morfemas relacionais”) são os itens lexicais cuja significação (gramatical e morfossemântica) só se estabelece no eixo sintático, em sua inserção no contexto frástico. Exemplos de morfemas dependentes são as preposições, as conjunções e os artigos (LOPES, 2013).

${ }^{28} \mathrm{E}$ isso não apenas no âmbito da investigação, mas também na esfera do ensino. No Curso de Língua Estrangeira Moderna Espanhol da UFBA, por exemplo, o novo currículo (que ainda entrará em vigor) não mais contará com os componentes curriculares Morfologia da Língua Espanhola e Sintaxe da Língua Espanhola, mas, sim, Morfossintaxe I da Língua Espanhola e Morfossintaxe II da Língua Espanhola.

${ }^{29}$ Como o morfema, a unidade morfológica por excelência, é dotado de uma natureza paradigmática e sintagmática, a morfologia deve se aplicar, portanto, ao estudo dessas duas facetas de seu objeto epistemológico.
} 
“bondosamente” etc.), que são advérbios modais. Além disso, segundo Vilela (1986) e em consonância com o apontado no parágrafo precedente, nota-se que a derivação e a sintaxe se utilizam de categorias semelhantes (como agente, predicado, objeto etc.), embora materializadas em elementos formais de desigual extensão e de diferente natureza, o que pode ser observado ao se cotejar o derivado "vendedor" e a construção frasal "O homem que vende X" ("calçados”, por exemplo), concluindo-se que são semanticamente equipolentes, intercambiáveis. Como afirma o próprio Vilela (1986, p. 33): “É certo que a formação de palavras e a sintaxe têm muito de comum [...]”.

A Nueva Gramática de la Lengua Española - NGLE (RAE; AALE, 2009), obra de referência para o estudo dessa língua, também elenca uma série de aspectos e fenômenos que demonstram as íntimas relações entre a lexicogênese morfológica e a sintaxe. Assim, tanto no espanhol quanto no português, é possível entrever a origem sintática de diversos afixos/afixoides, como o -mente, o ex- e o não-, via fluxos de gramaticalização, como já exposto em seção anterior, neste artigo. No tocante à composição, além da organização/concatenação interna entre as partes dos próprios compostos, uma exemplificação de suas relações limítrofes com a sintaxe é dada por algumas estruturas semilexicalizadas que são constituídas por substantivos ("peixe-espada”, “caneta-tinteiro”, “teste-relâmpago” etc.), que, como sinaliza a supramencionada gramática (RAE; AALE, 2009), são analisadas por alguns linguistas como estruturas sintáticas de natureza apositiva e, por outros, como verdadeiras palavras compostas.

Algumas considerações podem ser feitas a respeito do caráter sintático/sintagmático da formação de palavras via prefixação: como também distingue a NGLE (RAE; AALE, 2009), diversos prefixos antonímicos (pre- e pós-, extra- e intra-, anti- e pro-, contra- e pro-, por exemplo), quando relacionados na sintaxe, mostram-se de fato regidos por efeitos de verdadeira coordenação sintática (embora não deixem de ser partículas mórficas, ou seja, sublexicais e subsintáticas), como na estrutura "Há toda uma série de cuidados pré e pós-operatórios”; além disso, se atém-se à função sintática interna dos elementos prefixais, quase sempre, como afirma Sandmann (1992, 1997), ocorre uma sequência DT (determinante) — DM (determinado), em que o prefixo desempenha o papel de adjunto adnominal ou adverbial, constituindo o determinante da palavra complexa gerada. A maioria dos prefixos em português e em espanhol não costuma modificar a estrutura argumental de suas bases léxicas. Assim, como apontam Varela e Martín García (1999, p. 4999):

A diferencia de los sufijos, los cuales suelen cambiar la estructura argumental de sus bases léxicas, la mayoría de los prefijos del español mantienen los mismos argumentos del predicado léxico al que se unen. Sólo unos pocos prefijos producen alguna alteración en la estructura argumental de la base léxica, si bien estos cambios argumentales no se producen de forma general y sistemática en todas las palabras complejas que incluyen el prefijo con ese determinado valor semántico. Hay prefijos que añaden simplemente un argumento (Juan calla $>$ Juan acalla los rumores), con la posibilidad adicional de convertir un complemento argumental del predicado simple en un argumento implícito, que puede omitirse (Juan vive en Madrid > Juan convive (en Madrid) con su novia). En otros casos, el prefijo cambia la proyección sintáctica del argumento del predicado simple, el cual puede ser un complemento bien regido (El clavo ha pasado por la pared > El clavo ha traspasado la pared; El piloto vuela sobre el lago Ontario $>$ El piloto sobrevuela 
el lago Ontario) bien opcional, en cuyo caso lo convierte en complemento regido por el predicado complejo (Sacaron las bolas negras (de entre las brancas) > Entresacaron las bolas negras *(de entre las blancas)). ${ }^{30}$ (VARELA; MARTÍN GARCÍA, 1999, p. 4999, grifos dos autores).

Como notado por Alves (2000), a origem dos prefixos condiciona de certa forma a sua função junto à base a que se coadunam, de tal forma que os prefixos preposicionais (oriundos de uma preposição) funcionam como complemento subentendido dessa unidade, a exemplo de “contraveneno”, i.e., "remédio contra veneno”. Exercem função distinta, portanto, dos prefixos adverbiais, equivalentes semanticamente a um advérbio, já que modificam o significado da base lexical a que se acoplam: “redizer” denota “dizer novamente” (ALVES, 2000). Segundo Gonçalves (2012), os prefixos, ao contrário dos sufixos, jamais funcionam como cabeças semânticas — desse modo, não seriam tão densos semanticamente como os sufixos, que equivalem, em termos semânticos, a substantivos, segundo esse autor — , já que seus significados assemelham-se aos veiculados por adjetivos (como em “sub-humano”, “minimercado”, “megaempreendimento”), advérbios (como em “recapturar”, “antessala”, “pré-natal”, “pós-parto”) e preposições (como em “coautoria”, “intravenoso”, “entressafra”). ${ }^{31}$

Segundo as interessantes ilações de Rodrigues, V. V. (2010), seriam quatro (e não apenas dois, como comumente se afirma) os procedimentos sintáticos de articulação entre cláusulas ${ }^{32}$ : a coordenação, a subordinação, a correlação e a justaposição. Na coordenação, as cláusulas são sintaticamente independentes; na subordinação, uma das cláusulas manifesta dependência sintática em relação à outra; na correlação, as duas cláusulas são sintaticamente interdependentes; na justaposição, há uma combinação/encaixamento de cláusulas, sendo um arranjo discursivo em que está ausente o articulador (DECAT, 2001).

Se pensa-se, como dito anteriormente, em uma possível natureza sintática interna ao vocábulo, manifestada na concatenação ordenada e hierarquizada de seus constituintes morfológicos (radical, afixos, vogais temáticas, desinências etc.), que, além de propriedades associadas ao eixo paradigmático, possuem aquelas que são mais avizinhadas ao eixo sintagmático, poder-se-ia interrogar em qual dos tipos de concatenação/articulação se encaixariam os principais processos de formação de palavras: a sufixação, a composição e a prefixação. Não é supérfluo

\footnotetext{
30 "Diferentemente dos sufixos, que costumam modificar a estrutura argumental de suas bases lexicais, a maioria dos prefixos do espanhol mantêm os mesmos argumentos do predicado léxico a que se unem. Somente uns poucos prefixos produzem alguma alteração na estrutura argumental da base lexical, se bem que essas mudanças argumentais não se produzem de forma geral e sistemática em todas as palavras complexas que incluem o prefixo com esse valor semântico determinado. Há prefixos que acrescentam simplesmente um argumento (Juan calla > Juan acalla los rumores), com a possibilidade adicional de converter um complemento argumental do predicado simples em um argumento implícito, que pode ser omitido (Juan vive en Madrid > Juan convive (em Madrid) con su novia). Em outros casos, o prefixo modifica a projeção sintática do argumento do predicado simples, que pode ser um complemento obrigatoriamente regido (El clavo ha pasado por la pared > El clavo há traspasado la pared; El piloto vuela sobre el lago Ontario > El piloto sobrevuela el lago Ontario) ou opcional, em cujo caso o converte em um complemento regido pelo predicado complexo (Sacaron las bolas negras (de entre las brancas) > Entresacaron las bolas negras * (de entre las blancas)).” (VARELA; MARTÍN GARCÍA, 1999, p. 4999, grifos dos autores, tradução nossa).

${ }^{31}$ Exemplos como "benigno”, “circundar”, “contrário”, “entranhas”, “estranho”, “inferior”, “inferno”, “maldade”, “maligno” e "superior” levam a matizar essa generalização proposta por Gonçalves (2012), de que os prefixos nunca se comportam como o núcleo significativo do vocábulo, visto que, nesses exemplos, os prefixos (lexicalizados, deixe-se claro) realmente funcionam como cabeça semântica, comportando-se como morfemas lexicais básicos.

${ }^{32}$ Por inserir-se no marco funcionalista, a proposta de Rodrigues, V. V. (2010) não adota o termo "oração”, mas, sim, o termo “cláusula”, entendida como uma unidade informacional que pode ou não ter um verbo. Adota também o termo "articulador” (simples, composto ou correlativo) em vez de “conjunção”, por considerar aquele mais amplo e mais adequado que este.
} 
salientar que tal comparação entre arranjo de cláusulas e processos morfológicos aditivos de constituição vocabular é uma especulação inicial, um esboço e, como tal, é desprovida de qualquer pretensão de denotar afirmações categóricas sobre o que quer que seja. Trata-se, em suma, de uma comparação lato sensu, de caráter experimental.

Para proceder-se à comparação mencionada anteriormente, alguns ajustes precisariam ser feitos. Inicialmente, como se trata de categorias morfológicas, provavelmente seria mais adequado substituir os termos “principal” e "subordinado/a” (que se aplicam às cláusulas/orações integradas em uma articulação) pelos termos “nuclear” e “subsidiário” (ou “complementar”). No âmbito dessa proposta inicial de cotejo, talvez se possa pensar nas seguintes correspondências:

Figura 2: Esquema de correspondência dos tipos de articulação entre cláusulas (sintaxe) e dos tipos de articulação entre morfemas (morfologia lexical)

\begin{tabular}{|c|c|c|}
\hline NOÇÃo & $\begin{array}{c}\text { FENÔMENO } \\
\text { SINTÁTICO }\end{array}$ & $\begin{array}{c}\text { FENÔMENO } \\
\text { MORFOLÓGICO }\end{array}$ \\
\hline $\begin{array}{c}\text { Independência entre os elementos } \\
\text { relacionados }\end{array}$ & Coordenação & Composição \\
\hline $\begin{array}{c}\text { Dependência de um elemento em } \\
\text { relação ao outro }\end{array}$ & Subordinação & Prefixação, Sufixação, Composição \\
\hline $\begin{array}{c}\text { Interdependência de um elemento } \\
\text { em relação ao outro }\end{array}$ & Correlação & Composição \\
\hline Mera combinação entre elementos & Justaposição & \\
\hline
\end{tabular}

Fonte: $\mathrm{O}$ autor.

A própria natureza semântica subsidiária dos prefixos leva a enquadrá-los como partículas envolvidas em um processo de "subordinação”, pois, por fornecerem uma informação semântica complementar ao núcleo mórfico das bases a que se coadunam, são a estas subordinadas semântica e sintaticamente (no sentido da cadeia sintagmática interna à formação léxica). Assim sendo, por exemplo, da mesma forma que no período "Ranulfo pediu que ela chegasse cedo" tem-se uma cláusula principal ("Ranulfo pede”) e uma cláusula substantiva objetiva direta ("que ela chegasse cedo”) a ela subordinada sintaticamente (e que a complementa semanticamente), nos derivados “desunião”, “extraterrestre”, "pró-governamental”, "rememorar” e “vice-prior”, tem-se um elemento principal/nuclear (as bases lexicais “união”, "terrestre”, "governamental”, "memorar”, "prior”) — que é cabeça semântica, morfológica e "sintática” da formação — e um elemento a ele subordinado, que lhe concede uma carga semântica subsidiária (nos exemplos, respectivamente, as noções de “privação”, “posição externa”, “posição ideológica favorável a”, “repetição”, “imediatamente inferior a”), desempenhando, como já dito anteriormente, um papel similar a um adjunto adnominal ou adverbial (em suma, um complemento).

Para as operações de adjunção sufixal também haveria um processo de dependência/subordinação entre os elementos da formação derivativa, mas com uma diferenciação em relação às operações com formantes prefixais: enquanto estes são dependentes semântica e "sintaticamente” das bases léxicas a que se aditam, aqueles seriam as cabeças (os núcleos) semântico-sintáticas dos esquemas derivativos, sendo as respectivas bases lexicais os complementos ou elementos "subordinados". Para constatar-se isso, basta analisar morfossemanticamente os 
produtos derivacionais “cantor” (“o que canta”), “reciclagem” (“ação ou resultado de reciclar”), "alunado” (“conjunto de alunos”), "vespeiro” ("habitação de vespas”), em que são os radicais (cant-, recicl-, alun-, vesp-) os elementos que complementam o significado geral expresso pelo formativo sufixal (-or, -agem, -ado, -eiro).

Os processos morfológicos compositivos ${ }^{33}$, por sua vez, poderiam corresponder, dependendo de cada caso, a processos sintáticos de correlação e justaposição, mas também (como os prefixos e sufixos) a processos sintáticos de subordinação. Isso corrobora o que expressa Varela (2005, p. 76) sobre a "sintaxe” do composto, já que: "Es posible reconocer ciertas relaciones entre los constituyentes del compuesto que reproducen, en el nivel léxico, las que se dan entre los constituyentes de la oración"34. Em compostos (justapostos ou aglutinados) como "aguardente”, “guarda-costas”, “saca-rolhas”, “porta-bandeira”, “paraquedas”, "navio-escola”, ‘sofá-cama”, “lava-pés”, “olho-de-sogra”, “louva-a-deus”, “pernalta”, “rasga-mortalha”, “trinca-ferro”, “lobo-marinho”, “bolsa-família”, “música-tema”, “mesa-redonda” etc., manifesta-se uma relação de subordinação entre núcleo e complemento, com o núcleo à esquerda. Em vocábulos compostos como "norte-americano”, “vanglória”, “meio-dia”, “segunda-feira”, processa-se igualmente uma relação de subordinação entre núcleo e complemento, mas em uma ordem inversa (núcleo à direita, de forma similar ao que ocorre em operações prefixais). Há ainda casos de compostos que são coordenados, sem subordinação de um elemento ao outro, configurando uma associação morfolexical plasmada em uma disposição hierárquica, sintática e semântica sempre equipolente. É o caso dos itens “claro-escuro”, “surdo-mudo”, “vai-e-vem”, “histórico-cultural”, "econômico-financeiro”35.

Nesta primeira aproximação a este tema da aplicação de uma perspectiva sintaticocentrista à esfera morfológica da língua, à formação de palavras, não foi detectada nenhuma operação morfolexical stricto sensu que corresponda ao que Rodrigues, V. V. (2010) compreende como procedimento sintático de correlação na articulação entre cláusulas, visto que não se encontrou nenhum exemplo de formação morfológica derivativa ou compositiva em que haja uma interdependência sintático-semântica de um elemento mórfico em relação a outro e que demonstre uma similitude ao que ocorre em períodos como "Hoje eu economizo mais do que trabalhava"; "Quanto mais a conheço, tanto mais a amo"; "Trabalhou tanto que adoeceu”, nos quais os termos sublinhados nas cláusulas formam um par correlativo. Não obstante, se pensa em outros fenômenos lexicogenéticos, que extrapolam o campo morfológico, poderia ser considerado correspondente à correlação (interdependência de um elemento em relação ao outro) o redobro total, que, segundo Macêdo (1978), já ocorria no indo-europeu e no latim, fazendo-se presente em diversas outras línguas (francês, iorubá, nambiquara, mundurukú, siciliano etc.), entre as quais o português: "bate-bate”, “corre-corre”, "lambe-lambe”, “lengalenga”, “mexe-mexe”, “pega-pega”, “pula-pula”, “quebra-quebra”, “reco-reco” etc. A interdependência entre

\footnotetext{
${ }^{33}$ Faz-se aqui um recorte, considerando-se apenas os esquemas construcionais compositivos nos quais atuam formas livres da língua, deixando-se de lado (pelo caráter sintético deste estudo) aqueles esquemas em que há a participação de temas cultos de origem greco-latina (como em “cardioprotetor”, “filantropo”, “geofísico”, “herbívoro”, "musicólogo”, “necrófilo”, “pediatra”, "xenófobo" etc.).

34 “É possível reconhecer certas relações entre os constituintes do composto que reproduzem, no nível lexical, as que se dão entre os constituintes da oração.” (VARELA, 2005, p. 76, tradução nossa).

${ }^{35}$ Varela (2005) apresenta exemplos da língua castelhana para os três tipos de enquadramento da composição: guardameta e bocacalle (subordinação, com núcleo à esquerda); maniatar e terrateniente (subordinação, com núcleo à direita); aguanieve e compraventa (coordenação).
} 
as unidades redobradas deixa-se entrever na esfera semântica, pois, embora formas livres, o sentido iterativo só emerge mediante a associação entre os dois elementos repetidos.

\section{À GUISA DE CONSIDERAÇÕES FINAIS}

Como explanado por Soledade (2012), as línguas apresentam-se como o entrelaçamento de subsistemas dinâmicos — que estão em constante processo de reestruturação —, sendo neles observáveis padrões gerais de organização de suas estruturas, manifestados, quanto ao léxico, principalmente, por meio dos processos de formação de palavras, que licenciam a produção e a interpretação de itens lexicais. "Más que conjuntos de palabras y reglas para combinar palabras, las lenguas son conjuntos de procedimientos semánticos y formales que permiten fabricar palabras, oraciones y textos."36 (MORERA, 2007, p. 1). As ilações expressas por esses dois linguistas levam a uma consideração do caráter precípuo da formação de palavras (procedimentos semântico-formais ou, em outros termos, morfolexicais) na configuração lexicogênica e estrutural da língua, sendo um setor de intersecção e confluência entre distintos domínios do sistema linguístico, em movimento constante no devir histórico, cuja riqueza se concentra no fato de se poder construir com um número limitado de bases lexicais e com um número restrito de afixos - plasmados por regras e esquemas morfológicos de concatenação e combinação — um número infinito de palavras (BASILIO, 2004; MORERA, 2007; SOLEDADE, 2004; PENA, 1999; RIO-TORTO, 1998; FERREIRO, 1997).

Afirma Lopes (2013, p. 173) que “[...] o eixo morfológico da língua só se permite perscrutar de forma acurada em interatividade com os outros eixos constitutivos do sistema linguístico, como a fonologia, a semântica, o léxico, a sintaxe, o discurso e a pragmática”. O intuito que perpassou este artigo foi apresentar algumas reflexões sobre tais interações, sempre copiosas e multiformes, focalizando aquelas estabelecidas entre a morfologia lexical e a sintaxe, a filologia e a gramaticalização.

Ainda que se tenha a consciência, como Machado Filho (2014), de que os limites da estruturação vocabular (sejam semânticos, fônicos ou morfológicos e — por que não — discursivos e pragmáticos) são tênues, com uma essência nem sempre apreensível, como um objeto multiface, escorregadio e proteiforme, há de convir-se que uma perspectiva interdisciplinar, multitemática, que englobe diversas áreas dos estudos linguísticos e fomente uma integração e um diálogo profícuos entre elas, serviria como lastro adequado para lidar-se cientificamente com um tema tão implexo como a formação de palavras, fenômeno de importância fulcral para a compreensão do léxico de uma língua e de sua tessitura têmporo-espacial-cultural. Ainda que de forma elementar e ensaística, foi este o escopo primordial que perpassou a proposta de escrita destas laudas, vistas como escólios embrionários para uma visão integradora e multidimensional projetada sobre a lexicogênese de natureza morfológica, nomeadamente a operada mediante a prefixação.

\footnotetext{
36 “Mais do que conjuntos de palavras e regras para combinar palavras, as línguas são conjuntos de procedimentos semânticos e formais que permitem construir palavras, orações e textos.” (MORERA, 2007, p. 1, tradução nossa).
} 


\section{REFERÊNCIAS}

ABADDE, C. M. de S. O campo lexical dos utensílios da culinária medieval a partir do Livro de Cozinha da Infanta D. Maria. In: CARDOSO, S. A. M.; MEJRI, S.; MOTA, J. A. (org.). Os dicionários: fontes, métodos e novas tecnologias. Salvador: Vento Leste, 2011. p. 249-270.

ALBUQUERQUE, A. F. de. A prefixação no léxico da publicidade na mídia escrita. 2010. 116 f. Dissertação (Mestrado em Linguística) - Universidade Federal de Pernambuco, Recife, 2010. Disponível em: https://repositorio.ufpe.br/handle/123456789/7664. Acesso em: 12 jan. 2013.

ALVES, I. M. Um estudo sobre a neologia lexical: os microssistemas prefixais do português contemporâneo. 2000. 594 f. Tese (Livre-Docência) — Faculdade de Filosofia, Letras e Ciências Humanas, Universidade de São Paulo, São Paulo, 2000.

AZEREDO, J. C. de. Fundamentos de gramática do português. Rio de Janeiro: Jorge Zahar, 2000.

BARRETO, T. M. M. Lexicalização e gramaticalização: processos independentes ou complementares? In: LOBO, T. et al. (org.). ROSAE: linguística histórica, história das línguas e outras histórias. Salvador: EDUFBA, 2012. p. 407-415. Disponível em: https://repositorio. ufba.br/ri/handle/ri/16749. Acesso em: 9 jun. 2020.

BASILIO, M. M. de P. Formação e classes de palavras no português do Brasil. São Paulo: Contexto, 2004.

BASILIO, M. M. de P. O léxico como conhecimento lexical: dados e estratégias. In: CONGRESSO INTERNACIONAL DE LINGUÍSTICA HISTÓRICA, 2., 2012. Handout oferecido pela autora ao público assistente da Mesa-redonda "Léxico", em 8 fev. 2012, Roraima. p. 1-2.

BASSETTO, B. F. Elementos de filologia românica: história interna das línguas românicas. São Paulo: EDUSP, 2010. v. 2.

BORBA, F. da S. Organização de dicionários: uma introdução à lexicografia. São Paulo: Editora UNESP, 2003.

CAETANO, M. do C. A meio caminho entre a derivação e a composição. Estudos linguísticos,

n. 5, p. 131-140, 2010. Disponível em: https://clunl.fcsh.unl.pt/wp-content/uploads/ sites/12/2017/07/M.-C.-Caetano-1.pdf. Acesso em: 16 abr. 2013.

CAMPOS, L. S. É o prefixóide um item lexical em processo de gramaticalização? In: CONGRESSO INTERNACIONAL DA ABRALIN, 2., 2001. Fortaleza, Anais [...]. Fortaleza: ABRALIN, 2001. p. 323-325. v. 2.

CAMPOS, L. S. O emprego do não como prefixo versus processos tradicionais de antonímia. In: CONGRESSO NACIONAL DE ESTUDOS LINGUÍSTICOS E LITERÁRIOS, 6., 2002. Feira de Santana, Anais [...]. Feira de Santana: CNELL, 2002. p. 1-7.

CAMPOS, L. S. A negação prefixal na história da língua portuguesa. 2004. 360 f. Tese (Doutorado em Letras e Linguística) — Instituto de Letras, Universidade Federal da Bahia, 
Salvador, 2004a. Disponível em: http://www.repositorio.ufba.br:8080/ri/bitstream/ri/28698/1/ TESE\%20Campos\%2C\%20Lucas\%20Santos.pdf. Acesso em: 9 jun. 2020.

CAMPOS, L. S. As primeiras ocorrências do emprego do não como prefixo. In: JORNADA NACIONAL DE ESTUDOS LINGUÍSTICOS, 20., 2004. João Pessoa, Anais [...]. João Pessoa: JNELL, 2004b. p. 1-10.

CAMPOS, L. S. O desempenho do não como prefixo no português brasileiro contemporâneo. In: COSTA, S. B. B.; MACHADO FILHO, A. V. L. (org.). Do português arcaico ao português brasileiro. Salvador: EDUFBA, 2004c. Disponível em: https://repositorio.ufba.br/ ri/bitstream/ufba/135/4/Do\%20portugues\%20arcaico\%20ao\%20portugues\%20brasileiro.pdf. Acesso em: 28 maio 2020.

CAMPOS, L. S. A negação prefixal nas Cartas da Bahia do Pe. Antonio Vieira. Estudos linguísticos e literários, n. 35-36, p. 147-155, jan./dez. 2007.

CAMPOS, L. S. O desenvolvimento do prefixo não. In: OLIVEIRA, K.; CUNHA E SOUZA, H. F.; SOLEDADE, J. (org.). Do português arcaico ao português brasileiro: outras histórias. Salvador: EDUFBA, 2009. p. 247-271. Disponível em: https://repositorio.ufba.br/ri/handle/ ufba/191. Acesso em: 2 dez. 2018.

CAPRA, F. O ponto de mutação. São Paulo: Cultrix, 1997.

CASTILHO, A. T. de. A gramaticalização. Estudos Linguísticos e Literários, n. 19, p. 25-64, mar. 1997.

CASTILHO, A. T. de. Linguística cognitiva e tradição funcionalista. Estudos Linguísticos, n. 32, p. 1-8, 2002.

CASTILHO, A. T. de. Proposta funcionalista de mudança linguística: os processos de lexicalização, semanticização, discursivização e gramaticalização na constituição das línguas. In: LOBO T.; RIBEIRO, I.; CARNEIRO, Z.; ALMEIDA, N. (org.). Para a história do português brasileiro. Salvador: EDUFBA, 2003. p. 223-296. v. 6, tomo 1.

CASTILHO, A. T. de. O problema da gramaticalização das preposições no Projeto para a História do Português Brasileiro. Estudos lingüísticos, n. 33, p. 982-988, 2004. Disponível em: http://www.gel.hospedagemdesites.ws/estudoslinguisticos/edicoesanteriores/4publicaestudos-2004/4publica-estudos2004-pdfs-comunics/o_problema_gramaticalizacao.pdf. Acesso em: 26 ago. 2020.

CASTILHO, A. T. de. Abordagem da língua como um sistema complexo. Contribuições para uma nova Linguística Histórica. In: CASTILHO, A. T. de et al. (org.). Descrição, história e aquisição do português brasileiro. Homenagem a Mary A. Kato. Campinas: Pontes; Fapesp, 2007. p. 329- 360.

CASTILHO, A. T. de. Mudança linguística multissistêmica. In: TRAVAGLIA, C.; MAGALHÃES, J. S. (org.). Múltiplas perspectivas em linguística: coletânea de trabalhos apresentados no $11^{\circ}$ Simpósio Nacional de Letras e Linguística e no $1^{\circ}$ Simpósio Internacional de Letras e Linguística. Uberlândia: Ed. da UFU, 2008. p. 505-518. Disponível em: http:// www.filologia.org.br/ileel/artigos/artigo_510.pdf. Acesso em: 14 nov. 2014. 
CASTILHO, A. T. de. An approach to language as a complex system. In: CASTILHO, A. T. de. (org.). História do Português de São Paulo. Campinas: Instituto de Estudos da Linguagem, 2009. p. 119-136.

CASTILHO, A. T. de. Para uma abordagem cognitivista-funcionalista da gramaticalização. In: HORA, D. da; ROSA FILHO, C. (org.). Para a História do Português Brasileiro. João Pessoa: Ideia; Editora Universitária, 2010. p. 272-283. v. 8.

CASTILHO, A. T. de. Construção coletiva de gramáticas descritivas: refletindo sobre a experiência brasileira. Revista da ABRALIN, n. especial, p. 13-31, 2011. Disponível em: https://revistas.ufpr.br/abralin/article/view/32343/20543. Acesso em: 14 nov. 2014.

CAVALIERE, R. S. Fonologia e morfologia na gramática científica brasileira. Niterói: EDUFF, 2000.

CHAGAS, P. A mudança linguística. In: FIORIN, J. L. (org.). Introdução à linguística: objetos teóricos. São Paulo: Contexto, 2002. p. 141-163.

CHARTIER, R. As práticas da escrita. In: ARIÈS, P.; CHARTIER, R. (org.). História da vida privada: da Renascença ao século das luzes. São Paulo: Companhia das Letras, 2004. p. 113-158.

CORREIA, M.; ALMEIDA, G. M. de B. Neologia em português. São Paulo: Parábola, 2012. COSTA, S. B. B. Espaço e tempo em adverbiais portugueses quinhentistas. In: COSTA, S. B. B.; MACHADO FILHO, A. V. L. (org.). Do português arcaico ao português brasileiro. Salvador: EDUFBA, 2004. p. 47-66. Disponível em: https://repositorio.ufba.br/ri/bitstream/ ufba/135/4/Do\%20portugues\%20arcaico\%20ao\%20portugues\%20brasileiro.pdf. Acesso em: 28 maio 2020.

COSTA, S. B. B. Adverbiais espaciais e temporais do português: indícios diacrônicos de gramaticalização. 2003. 416 f. Tese (Doutorado em Letras e Linguística) — Instituto de Letras, Universidade Federal da Bahia, Salvador, 2003.

COSTA, S. B. B. Fontes lexicais de adverbiais espaciais e temporais portugueses. In: OLIVEIRA, K.; CUNHA E SOUZA, H. F.; SOLEDADE, J. (org.). Do português arcaico ao português brasileiro: outras histórias. Salvador: EDUFBA, 2009. p. 77-99.

COSTA, S. B. B. Adverbiais espaciais e temporais portugueses: trajetos léxico-semânticos. In: LOBO, T. et al. (org.). ROSAE: linguística histórica, história das línguas e outras histórias. Salvador: EDUFBA, 2012. p. 417-440.

CUENCA, M. J.; HILFERTY, J. Introdución a la lingüística cognitiva. Barcelona: Ariel, 1999. CUNHA E SOUZA, H. F. Edições e suportes: A Vida e Feitos de Júlio César do papel ao digital. In: SEMINÁRIO DE ESTUDOS FILOLÓGICOS, 2., 2007. Salvador, Anais [...]. Salvador: Quarteto, 2007. p. 253-258.

DECAT, M. B. N. A articulação hipotática adverbial no português em uso. In: DECAT, M. B. N. et al. (org.). Aspectos da gramática do português: uma abordagem funcionalista. Campinas: Mercado de Letras, 2001. p. 103-166. v. 5. 
DELANCEY, S. Grammaticalization: from syntax to morphology. In: BOOIJ, G. et al. (org.). Morphologie: ein internationales Handbuch zur Flexion und Wortbildung. Berlin; New York: De Gruyter, 2000. p. 1590-1599.

DEPUYDT, E. Los prefijos de intensificación en español: archi-, extra-, super- y ultra-. 2009. 120 f. Dissertação (Master in de Taal — en Letterkunde) — Faculteit Letteren en Wijsbegeerte, Universiteit Gent, Gent, 2009. Disponível em: https://lib.ugent.be/fulltxt/ RUG01/001/414/729/RUG01-001414729_2010_0001_AC.pdf. Acesso em: 4 out. 2013.

DIVINO, R. G. F.; PIRES, J. A. O. Formação de palavras e visões alternativas nas relações morfossintáticas. Episteme Transversalis, Volta Redonda, v. 9, n. 2, p. 76-93, 2018. Disponível em: http://revista.ugb.edu.br/ojs302/index.php/episteme/article/view/982. Acesso em: 30 ago. 2020.

DUARTE, P. M. T. O não: formador de palavras em português? Revista do GELNE, Natal, v. 1, n. 2, p. 67-70, 1999. Disponível em: https://periodicos.ufrn.br/gelne/article/view/9263. Acesso em: 25 ago. 2020.

ECO, U. Da árvore ao labirinto. Tradução de Maurício Santana Dias. Rio de Janeiro; São Paulo: Record, 2013.

EVANS, V. A Glossary of Cognitive Linguistics. Edinburgh: Edinburgh University Press, 2007.

FERNÁNDEZ JAÉN, J. Cambio semántico, teoría de prototipos y gramaticalización: un acercamiento. In: CONGRESO NACIONAL DE LA ASOCIACIÓN DE JÓVENES INVESTIGADORES DE LA LENGUA ESPAÑOLA, 8., 2008. Barcelona, Actas [...]. Barcelona: Universitat de Barcelona, 2009. p. 67-71.

FERREIRA, P. S. Edição dos documentos dionisinos do livro $2^{\circ}$ das Inquirições de Afonso XIII: edição crítica de textos medievais não literários em língua portuguesa. 2003. xli f. + 196 f. Tese (Doutorado em Letras) — Faculdade de Filosofia, Letras e Ciências Humanas, Universidade de São Paulo, São Paulo, 2003.

FERREIRO, M. Gramática histórica galega: lexicoloxía. Santiago de Compostela: Laiovento, 1997.

FLOOD, R.L.; CARLSON, E. R. Dealing with complexity: an introduction to the theory and application of systems science. New York: Plenum Press, 1988.

GARCÍA PLATERO, J. M. Consideraciones sobre la formación de palabras en español. E.L.U.A., Alicante, n. 12, p. 69-78, 1998. Disponível em: http://rua.ua.es/dspace/ handle/10045/6328. Acesso em: 4 out. 2013.

GONÇALVES, C. A. V. Compostos neoclássicos: estrutura e formação. ReVEL, [s.l.], edição especial, n. 5, p. 6-39, 2011a. Disponível em: http://www.revel.inf.br/files/artigos/revel_ esp_5_compostos.pdf. Acesso em: 26 jul. 2013.

GONÇALVES, C. A. V. Composição e derivação: polos prototípicos de um continuum? Pequeno estudo de casos. Domínios de lingu@gem, Uberlândia, v. 5, n. 2, jul./dez. 2011 b. Disponível em: http://www.seer.ufu.br/index.php/dominiosdelinguagem/article/view/13644. Acesso em: 30 ago. 2013. 
GONÇALVES, C. A. V. Prefixação: composição ou derivação? Novos enfoques sobre uma velha polêmica. Matraga, Rio de Janeiro, v. 19, p. 56-90, 2012. Disponível em: https:// www.e-publicacoes.uerj.br/index.php/matraga/article/view/22625. Acesso em: 11 out. 2013.

GONÇALVES, C. A. V. Atuais tendências em formação de palavras. São Paulo: Contexto, 2016a.

GONÇALVES, C. A. V. Morfologia construcional: uma introdução. São Paulo: Contexto, $2016 b$.

GRAS, P. Gramática de construcciones en interacción: propuesta de un modelo y aplicación al análisis de estructuras independientes con marcas de subordinación en español. 2010. 581 f. Tese (Doctorado en Filología Española) - Facultat de Filología, Universitat de Barcelona, Barcelona, 2010. Disponível em: https://www.tdx.cat/handle/10803/1716\#page=1. Acesso em: 30 ago. 2017.

GROSSMANN, M.; RAINER, F. (org.). La formazione delle parole in italiano. Tübingen: Max Niemeyer Verlag, 2004.

HEINE, B.; ULRIKE, C.; HÜNNEMEYER, F. Grammaticalization: a conceptual framework. Chicago: University of Chicago Press, 1991.

HOPPER, P. J. On some principles of grammaticization. In: TRAUGOTT, E.; HEINE, B. Approaches to grammaticalization: focus on types of grammatical markers. Amsterdam: John Benjamins, 1991. p. 17-35.

HOPPER, P. J.; TRAUGOTT, E. C. Grammaticalization. Cambridge: Cambridge University Press, 1993.

IACOBINI, C. Prefissazione. In: GROSSMANN, M.; RAINER, F. (org.). La formazione delle parole in italiano. Tübingen: Max Niemeyer Verlag, 2004. p. 98-163.

IBARRETXE-ANTUÑANO, I. Humanismo, ciencia y lingüística (cognitiva): ¿incompatibles o complementarios? In: QUEROL BATALLER, M. (Ed.). El futuro de las humanidades: II volumen de artículos en homenaje al profesor D. Ángel López García. Valencia: Servei de Publicacions de la Universitat de Valencia, 2010. p. 49-69.

JACOB, L. P. Não- derivação ou não- composição? Apontamentos sobre as formas não-X. In: COLÓQUIO INTERNACIONAL DE ESTUDOS LINGUÍSTICOS E LITERÁRIOS, 1., 2010. Maringá. Anais [...]. Maringá: UEM-PLE, 2010. p. 1-10.

KASPER, H. O processo de pensamento sistêmico: um estudo das principais abordagens a partir de um quadro de referência proposto. 2000. 291 f. Dissertação (Mestrado em Engenharia de Produção) - Escola de Engenharia, Universidade Federal do Rio Grande do Sul, Porto Alegre, 2000. Disponível em: https://lume.ufrgs.br/handle/10183/9013. Acesso em: 12 nov. 2014.

LABOV, W. Building on empirical foundations. In: LEHMANN, W.; MALKIEL, Y. (org.). Perspectives on historical linguistics. Amsterdan/Philadelphia: Jonh Benjamins, 1982. p. 17-92.

LAMIROY, B. La teoría de la gramaticalización y sus aplicaciones en las lenguas románicas. E.L.U.A., Alicante, n. extra 2, p. 245-266, 2004. Disponível em: https://core.ac.uk/download/ pdf/16363032.pdf. Acesso em: 12 fev. 2018. 
LANGACKER, R. W. Foundations of cognitive grammar: Theoretical prerequisites. Stanford: Stanford University Press, 1987. v. 1.

LEHMANN, C. Grammaticalization and related changes in contemporary German. In: TRAUGOTT, E. C.; HEINE, B. (Ed.). Approaches to grammaticalization. Amsterdam/ Philadelphia: John Benjamins, 1991. p. 493-535.

LEHMANN, C. Grammaticalization: synchronic variation and diachronic change. Lingua e Stile, [s. l.], n. 20, p. 308-318, 1985.

LEHMANN, C. Thoughts on grammaticalization: a programatic sketch. Cologne: Institut für Sprachwissenschaft, 1982. v. 1.

LOPES, M. A prefixação na primeira fase do português arcaico: descrição e estudo semântico-morfolexical-etimológico do paradigma prefixal da língua portuguesa nos séculos XII, XIII e XIV. 2013. 2v. 943 f. Dissertação (Mestrado em Língua e Cultura) — Instituto de Letras, Universidade Federal da Bahia, Salvador, 2013. Disponível em: https://repositorio. ufba.br/ri/handle/ri/15537. Acesso em: 13 dez. 2015.

LOPES, M. Estudo histórico-comparativo da prefixação no galego português e no castelhano arcaicos (séculos XIII a XVI): aspectos morfolexicais, semânticos e etimológicos. 2018. 2430 f. Tese (Doutorado em Língua e Cultura; Doutoramento em Linguística do Português) - Instituto de Letras/Faculdade de Letras, Universidade Federal da Bahia/ Universidade de Coimbra, Salvador/Coimbra, 2018. 5 v. Disponível em: https://repositorio. ufba.br/ri/handle/ri/29879. Acesso em: 3 dez. 2019.

LOPES, M. Prefixos, prefixoides, pseudoprefixos: uma proposta de refinamento terminológicoconceitual para os elementos afixais da margem esquerda do vocábulo. In: SEPEXLE SEMINÁRIO DE PESQUISA E EXTENSÃO EM LETRAS DA UESC, 6., 2014. Ilhéus, Anais [...]. Ilhéus: UESC, 2014. p. 211-222. Disponível em: http://www.uesc.br/eventos/ sepexle/visepexle/anais_visepexle2014.pdf. Acesso em: 14 set. 2015.

LOPES, M.; SOLEDADE, J. Algumas considerações gerais atinentes ao fenômeno da prefixação na primeira fase do português arcaico (séculos XII-XIV). Cadernos do NEMP, Rio de Janeiro, v. 4, n. 1, p. 61-77, 2013. Disponível em: https://www.nemp-rj.com/cadernos-5-1. Acesso em: 22 dez. 2015.

MACÊDO, J. O redobro: um processo natural da linguagem? Universitas, Salvador, n. 19, p. 45-60, 1978. Disponível em: https://portalseer.ufba.br/index.php/universitas/article/ view/1226. Acesso em: 14 dez. 2015.

MACHADO FILHO, A. V. L. “Aquisse começa huũ exẽplo perque pode homẽ entẽder algũas diferenças antre dous manuscritos que de consuũ tratam da vida de Tassis molher que foy muy pecador”. Filologia e Lingüística Portuguesa, São Paulo, n. 4, p. 69-95, 2001. Disponível em: http://www.revistas.usp.br/flp/article/view/59691. Acesso em: 22 dez. 2015.

MACHADO FILHO, A. V. L. Um Flos Sanctorum do século XIV: edições, glossário e estudo lingüístico. 2003. 1109 f. Tese (Doutorado em Letras e Linguística) — Instituto de Letras, Universidade Federal da Bahia, Salvador, 2003. 
MACHADO FILHO, A. V. L. Diálogos de São Gregório: edição e estudo de um manuscrito medieval português. Salvador: EDUFBA; Mosteiro de São Bento da Bahia, 2008.

MACHADO FILHO, A. V. L. Um Flos Sanctorum trecentista em português. Brasília: Editora da Universidade de Brasília, 2009a.

MACHADO FILHO, A. V. L. Relativa unidade da língua. A Tarde, Salvador, 7 mar. 2009b. Caderno Especial, p. 3.

MACHADO FILHO, A. V. L. Lexicografia histórica e questões de método. In: LOBO, T. et al. (org.). ROSAE: linguística histórica, história das línguas e outras histórias. Salvador: EDUFBA, 2012. p. 381-389. Disponível em: https://repositorio.ufba.br/ri/handle/ri/16749. Acesso em: 9 jun. 2020.

MACHADO FILHO, A. V. L. Pequeno vocabulário do português arcaico. Brasília: Editora Universidade de Brasília; Salvador: EDUFBA, 2014.

MAIA, C. de A. Linguística histórica e filologia. In: LOBO, T. et al. (org.). ROSAE: linguística histórica, história das línguas e outras histórias. Salvador: EDUFBA, 2012. p. 533542. Disponível em: https://repositorio.ufba.br/ri/handle/ri/16749. Acesso em: 9 jun. 2020.

MARQUILHAS, R. Níveis de alfabetização na sociedade portuguesa seiscentista. In: MARQUILHAS, R. (org.). A faculdade das letras: leitura e escrita em Portugal, séc. XVII. Lisboa: Imprensa Nacional - Casa da Moeda, 2000. p. 83-140.

MARTIN, R. Para entender a linguística: epistemologia elementar de uma disciplina. Tradução de Marcos Bagno. São Paulo: Parábola, 2003.

MATEUS, M. H. M. Saudação. In: LOBO, T. et al. (org.). ROSAE: linguística histórica, história das línguas e outras histórias. Salvador: EDUFBA, 2012. p. 13-18. Disponível em: https://repositorio.ufba.br/ri/handle/ri/16749. Acesso em: 9 jun. 2020.

MATTOS E SILVA, R. V. Estruturas trecentistas: elementos para uma gramática do português arcaico. Salvador: EDUFBA, 2010.

MATTOS E SILVA, R. V. O português arcaico: fonologia, morfologia e sintaxe. São Paulo: Contexto, 2006.

MATTOS E SILVA, R. V. O português arcaico: fonologia. São Paulo: Contexto; Bahia: EDUFBA, 1991.

MEILLET, A. Linguistique historique et linguistique générale. Paris: Edouard Champion, 1948 [1912].

MENDES, A. Processos de gramaticalização. In: RAPOSO, E. P. et al. (Ed.). Gramática do português. Lisboa: Calouste Gulbenkian, 2013. p. 247-293. v. 1.

MINUSSI, R. D.; NÓBREGA, V. A. A interface sintaxe-pragmática na formação de palavras: avaliando os pontos de acesso da Enciclopédia na arquitetura da gramática. Veredas, Juiz de Fora, v. 18, n. 1, p. 161-184, 2014. Disponível em: https://www.ufjf.br/revistaveredas/ files/2014/07/09-Minussi_Nobrega-1.pdf. Acesso em: 29 ago. 2020. 
MÓDOLO, M. Gramaticalização e semanticização das conjunções correlativas 'sem cabeça': o caso do que consecutivo. In: LOBO, T. et al. (org.). ROSAE: linguística histórica, história das línguas e outras histórias. Salvador: EDUFBA, 2012. p. 441-451. Disponível em: https:// repositorio.ufba.br/ri/handle/ri/16749. Acesso em: 9 jun. 2020.

MÓDOLO, M.; BRAGA, H. Uma teoria brasileira do idioma: professor da USP apresenta uma sedutora e abrangente proposta de análise da mudança linguística para o português brasileiro. Língua Portuguesa, São Paulo, v. 78, p. 26-27, 2012.

MORERA, M. La gramática del léxico español. Badajoz: Abecedario, 2007.

MORIN, E. A cabeça bem-feita: repensar a reforma, reformar o pensamento. 8. ed. Tradução de Eloá Jacobina. Rio de Janeiro: Bertrand Brasil, 2003.

NASCIMENTO, A. K. G. De 'idólatra' a 'chocólatra': uma análise morfossemântica das construções em X-latra. In: CASTILHO - CONGRESSO INTERNACIONAL DE LINGUÍSTICA HISTÓRICA, 2., 2012. Painel exposto pela autora ao público assistente do congresso, em 8 fev. 2012.

OLIVEIRA, M. M. da S. de. Análise de prevérbios e prefixos, oriundos de preposições latinas, utilizados na formação de verbos, substantivos e adjetivos a partir das bases -fer- e -lat-. Marginahlia, [s.l.], n. 2, p. 35-47, jul./dez. 2007.

PENA, J. La palabra: estructura y procesos morfológicos. Verba, Santiago de Compostela, n. 18, p. 69-128, 1991.

PENA, J. Partes de la morfología: las unidades del análisis morfológico. In: BOSQUE, I.; DEMONTE, V. (org.). Gramática descriptiva de la lengua española. Madrid: Espasa, 1999. p. 4305-4366.

PENA, J. Sobre la definición del morfema. LEA, Madrid, n. XVII, v. 2, p. 129-141, 1995.

PETRUCCI, A. La ciencia de la escritura: primera lección de paleografía. Buenos Aires: Fondo de Cultura Econômica de Argentina, 2003.

POGGIO, R. M. G. F. Processos de gramaticalização de preposições do latim ao português: uma abordagem funcionalista. Salvador: EDUFBA, 2002.

REAL ACADEMIA ESPAÑOLA; ASOCIACIÓN DE ACADEMIAS DE LA LENGUA ESPAÑOLA. Nueva gramática de la lengua española - NGLE. Madrid: Espasa, 2009. v. 1. RIO-TORTO, G. M. Morfologia derivacional: teoria e aplicação ao português. Porto: Porto, 1998.

RIO-TORTO, G. M. Prefixação. In: RIO-TORTO, G. M. et al. (coord.). Gramática derivacional do português. 2. ed. Coimbra: Imprensa da Universidade de Coimbra, 2016. p. 411-459.

RODRIGUES, A. F. S. Noções basilares sobre a morfologia e o léxico. In: RIO-TORTO, G. et al. (coord.). Gramática derivacional do português. Coimbra: Imprensa da Universidade de Coimbra, 2016. p. 35-133. 
RODRIGUES, C. V. Derivados verbais construídos com prefixos de localização duas regras? Graphos, [s.l.], v. 5, n. 1, p. 7-20, 2000.

RODRIGUES, V. V. (Org.). Articulação de orações: pesquisa e ensino. Rio de Janeiro: UFRJ, 2010.

ROMANELLI, R. C. Os prefixos latinos: da composição verbal e nominal, em seus aspectos fonético, morfológico e semântico. Belo Horizonte: Imprensa da Universidade de Minas Gerais, 1964.

SÁNCHEZ-PRIETO BORJA, P. Alternancia entre el lexema con y sin prefijo en castellano medieval: el verbo. In: CONGRESO INTERNACIONAL DE HISTORIA DE LA LENGUA ESPAÑOLA, 2., 1992, Madrid. Actas [...]. Madrid: Pabellón de España, 1992. p. 1323-1336. v. I. Disponível em: https://ebuah.uah.es/dspace/handle/10017/7216. Acesso em: 11 jan. 2013.

SANDMANN, A. J. Morfologia geral. 3. ed. São Paulo: Contexto, 1997.

SANDMANN, A. J. Morfologia lexical. São Paulo: Contexto, 1992.

SANTOS, A. V. Do composto sintagmático ao lexema aglutinado: consequências morfológicas e sintáticas. In: MATTOS E SILVA, R. V.; OLIVEIRA, K.; AMARANTE, J. (org.). Várias navegações: português arcaico, português brasileiro, cultura escrita no Brasil, outros estudos. Salvador: EDUFBA, 2012. p. 239-258. Disponível em: https://repositorio.ufba.br/ri/handle/ ri/17758. Acesso em: 22 maio 2020.

SHARPE, J. A história vista de baixo. In: BURGE, P. (org.). A escrita da história: novas perspectivas. Tradução de Magna Lopes. São Paulo: Editora da UNESP, 1992. p. 39-62.

SILVA, L. C. C. Prefixos latinos de movimento: um estudo morfológico e lexicográfico. 2006. 184 f. Tese (Doutorado em Letras) — Faculdade de Ciências e Letras, Universidade Estadual Paulista, Araraquara, 2006. Disponível em: https://repositorio.unesp.br/handle/11449/103589. Acesso em: 8 set. 2012.

SOLEDADE, J. A antroponímia no português arcaico: aportes sobre a sufixação em nomes personativos. In: LOBO, T. et al. (org.). ROSAE: linguística histórica, história das línguas e outras histórias. Salvador: EDUFBA, 2012. p. 323-336. Disponível em: https://repositorio. ufba.br/ri/handle/ri/16749. Acesso em: 9 jun. 2020.

SOLEDADE, J. Para um entendimento da morfologia lexical da língua portuguesa a partir de Guimarães Rosa. 1999. 150 f. Monografia (Bacharelado em Letras) — Instituto de Letras, Universidade Federal da Bahia, Salvador, 1999.

SOLEDADE, J. Semântica morfolexical: contribuições para a descrição do paradigma sufixal do português arcaico. 2004. 575 f. Tese (Doutorado em Letras e Linguística) — Instituto de Letras, Universidade Federal da Bahia, Salvador, 2004. 2 v.

STEIN, G. Zur Typologie der Suffixentstehung: Französisch, Englisch, Deutsch. Indogermanische Forschungen, Berlin, n. 75, p. 131-165, 1970. 
SWIGGERS, P. Filologia e lingüística: enlace, divórcio, reconciliação. Tradução de Lineide do Lago Salvador Mosca. Filologia e lingüística portuguesa, São Paulo, n. 2, p. 5-18, 1998. Disponível em: http://www.revistas.usp.br/flp/article/view/59656. Acesso em: 25 jan. 2015.

TELLES, C. M. Achega ao vocabulário de cozinha. In: CARDOSO, S. A. M.; MEJRI, S.; MOTA, J. A. (org.). Os dicionários: fontes, métodos e novas tecnologias. Salvador: Vento Leste, 2011. p. 371-393.

TELLES, C. M. Mudanças lingüísticas e crítica textual. Estudos linguísticos e literários, Salvador, n. 25/26, p. 91-119, jan./dez. 2000.

VARELA, S. Morfología léxica: la formación de palabras. Madrid: Gredos, 2005.

VARELA, S.; MARTÍN GARCÍA, J. La prefijación. In: BOSQUE, I.; DEMONTE, V. (org.). Gramática descriptiva de la lengua española. Madrid: Espasa, 1999. p. 4993-5040.

VASCONCELlOS, M. J. E. de. Pensamento sistêmico: o novo paradigma da ciência. Campinas: Papirus, 2002.

VILELA, M. A formação de palavras: componente independente ou apenas subcomponente? Línguas e Literaturas, Porto, v. 3, p. 31-52, 1986. Disponível em: http://ojs.letras.up.pt/ index.php/rll/article/view/8469. Acesso em: 29 ago. 2020.

VILLALVA, A. Morfologia do português. Lisboa: Universidade Aberta, 2008.

WALLERSTEIN, I. The modern world-system: capitalist agriculture and the origins of the European world-economy in the sixteenth century. Berkeley; Los Angeles: University of California Press, 2011 [1974]. v. 1. Disponível em: cfile205.uf.daum.net/ attach/2744C33754D5B4E31DF586. Acesso em: 12 fev. 2013.

ZANOTTO, N. Estrutura mórfica da língua portuguesa. Caxias do Sul: EDUCS, 1986.

Recebido em: jun. 2020.

Aceito em: set. 2020. 